\title{
'Poisoned Chalice': Law on Access to Biological and Genetic Resources and Associated Traditional Knowledge in Namibia
}

\author{
Wana W. Chinsembu ${ }^{1,2}$ and Kazhila C. Chinsembu ${ }^{3, *}$ \\ 1 Justice Training Centre, University of Namibia, Private Bag 13301, Windhoek, Namibia; \\ wana.chinsembu@gmail.com \\ 2 Formerly, Faculty of Law, Department of Commercial Law, University of Cape Town, Private Bag X3, \\ Rondebosch 7701, South Africa \\ 3 Faculty of Science, Department of Biological Sciences, University of Namibia, Private Bag 13301, \\ Windhoek, Namibia \\ * Correspondence: kchinsembu@unam.na or kchinsembu@gmail.com; Tel.: +264-61-2063426; \\ Fax: +264-61-2063791
}

Received: 28 August 2018; Accepted: 24 October 2018; Published: 3 July 2020

\begin{abstract}
Many countries in Africa provide ethnobiological resources (more especially ethnomedicinal plants), which are converted by companies and users from developed countries into biopharmaceutical products without any monetary benefits to the countries of origin. To mitigate the lack of benefits, African countries are beginning to enact access and benefit-sharing (ABS) legislation, though their wheels turn very slowly. Since many African ABS laws have not been appraised for their feasibility, this paper presents a contextual analysis of Namibia's new ABS law: The Access to Biological and Genetic Resources and Associated Traditional Knowledge Act No. 2 of 27 June 2017. Even if several international conventions on ABS and local institutional structures guided the evolution of the 2017 Act, the main drivers for the enactment of the ABS legislation in Namibia are: Inequitable sharing of monetary benefits from the green economy, putative, but unproven cases of biopiracy, and political power contestations over ethnobiological resources. A critical analysis of important challenges faced by Namibia's new ABS law include: Lack of adequate participatory consultations and technical capacity at the local level, discount of the non-commodity cultural value of TK, ambiguous and narrow definition of the term 'community', lack of a clause on confidentiality, and assertions that the new ABS law negatively impacts research in Namibian universities and botanic gardens. In contrast to South Africa's ABS law, Namibia's law is more onerous because it does not differentiate between commercial and non-commercial research.
\end{abstract}

Keywords: access; benefit-sharing; ethnobiological resources; traditional knowledge; Namibia

\section{Introduction}

Knowledge, not capital, is the most critical resource for sustainable socioeconomic development [1], and traditional knowledge (TK) is an important foundation for innovative interventions in education, health, agriculture, and biotechnology [2]. TK of medicinal plants, for example, is an important technical pillar in bioprospecting, the search for species from which medicinal drugs and other commercially-valuable chemical compounds can be extracted [3]. As seen in China, qinghaosu (artemisinin) emerged from a strong screening pipeline premised on the TK of sweet wormwood, Artemisia annua, an ethnomedicinal plant used against malaria [4]. The discovery of artemisinin earned the Chinese scientist, Tu Youyou, the shared 2015 Nobel Prize in Physiology or 
Medicine [5]. Guided by ancient Chinese texts, Tu's screening of ethnomedicinal plants produced a promising antimalarial principle from an extract of $A$. annua [6].

Modern pharmacopoeias contain many drugs initially sourced from ethnomedicinal plants used in traditional settings [7]. Careful review of ancient texts about the medico-botanical knowledge of traditional healers, sometimes called barefoot doctors, is a short-cut to the discovery of pharmacologically-active compounds that may be developed into novel drugs [8]. The exploratory work of botanists tapping into the rich vein of TK of medicinal plants serves as a promising starting-point for drug discovery [9]. Access to the TK of medicinal plants provides crucial leads toward therapeutic concept thereby accelerating drug development. The commodification of TK for drug discovery, also known as reverse pharmacology [10], is a spin-off from ethnobotany, a term coined during the Scramble for Africa between 1881 and 1914 [11]. European colonialists inspired by commerce used ethnobotany to harness indigenous African plants with potential industrial and pharmaceutical value. It is not a coincident, therefore, that at the peak of the Scramble for Africa, the pharmaceutical company, Bayer, was established in Germany circa 1887 [12].

The confluence of ethnobotany and bioprospecting feeds into the farmer-to-pharma paradigm whose profit-making rationality is that natural products that are not chemically screened present a lost and wasted opportunity in the innovation of blockbuster drugs [13]. TK is an invisible, but powerful, conveyor belt for multi-billion dollar pharmaceutical and cosmetics industries [14]. However, bioprospecting is hardly a commercially-benign activity [15], and the annual global market for healthcare, agriculture, and biotechnology products derived from TK-based resources was estimated at US\$500-800 billion [16]. By the late 1980s, it was becoming increasingly clear that with advancements in technological research and innovation, ethnobiological and genetic resources, and associated TK were invaluable ingredients for commercial product development in markedly profitable industries [17].

Although intellectual property (IP) law readily recognizes these 'innovations' by industry, it often turns a blind eye to the incremental contributions of TK holders and citizen scientists who are some of the world's poorest people [14]. Within this unfair and inequitable pecuniary milieu, access to ethnobiological and genetic resources and documentation of TK of medicinal plants are now viewed as entrepreneurial and profit-seeking activities taking place in highly politicized ecological and socioeconomic spaces [15]. The melding of conservation and capitalism [18], coupled with neoteric community-based instruments of environmental stewardship, have given governments and local communities new legal and mercantile spectacles through which to view access to shared ethnobiological resources and TK with potential applications in bioprospecting [19,20].

Given the global economic importance of bioprospecting, Namibia in June 2017, enacted the law on Access to Biological and Genetic Resources and Associated TK [21]; see Figure 1 for excerpts of the 2017 law. Namibia also has obligations to develop national legislation, being a party to the Nagoya Protocol since 12 October 2014. On paper, the 2017 Act summarily commits to quadruplicate aims: To regulate access to biological or genetic resources and associated TK; protect the rights of local communities over their biological and genetic resources and associated TK; provide for a fair and equitable mechanism for benefit-sharing; and establish the requisite administrative structures and processes for the implementation of access and benefit-sharing (ABS) principles and issuance of permits (Figure 1). The ABS law dovetails into President Hage Geingob's Harambee Prosperity Plan, a new narrative of economic populism promising wealth redistribution and poverty eradication by building an inclusive 'Namibian house' where economic benefits are shared equitably [22].

However, beyond the veneer of political orotundity, conceptual and legal underpinnings of the ABS Act are subject to shifting realities and perceptions as regulating access to Namibia's bioresources is perforated with historical and contemporary complexities. Even in its nascent stages, the Namibian ABS law was already encumbered with contradictions and contentious issues [23]. Worse still, usage of this ABS law to protect tacit and orally transmitted TK will require a herculean shift in the comprehension and dispensation of IP regulations. Although the practicality of Namibia's law on Access to Biological and Genetic Resources and Associated TK, Act No. 2 of 27 June 2017 is 
seemingly etched into a plethora of conundrums, no detailed studies have paid attention and analyzed these shortcomings. Moreover, Namibia's new law on ABS has not yet been appraised against the backdrop of international conventions on ABS. An analysis of local institutional structures, contextual bio-economic considerations, including cases of biopiracy [24], and ecological or political power contestations that heralded the current law has not yet been conducted. A critical examination of the new law in terms of its weaknesses and how it compares with similar ABS legislation in other countries is not yet available.

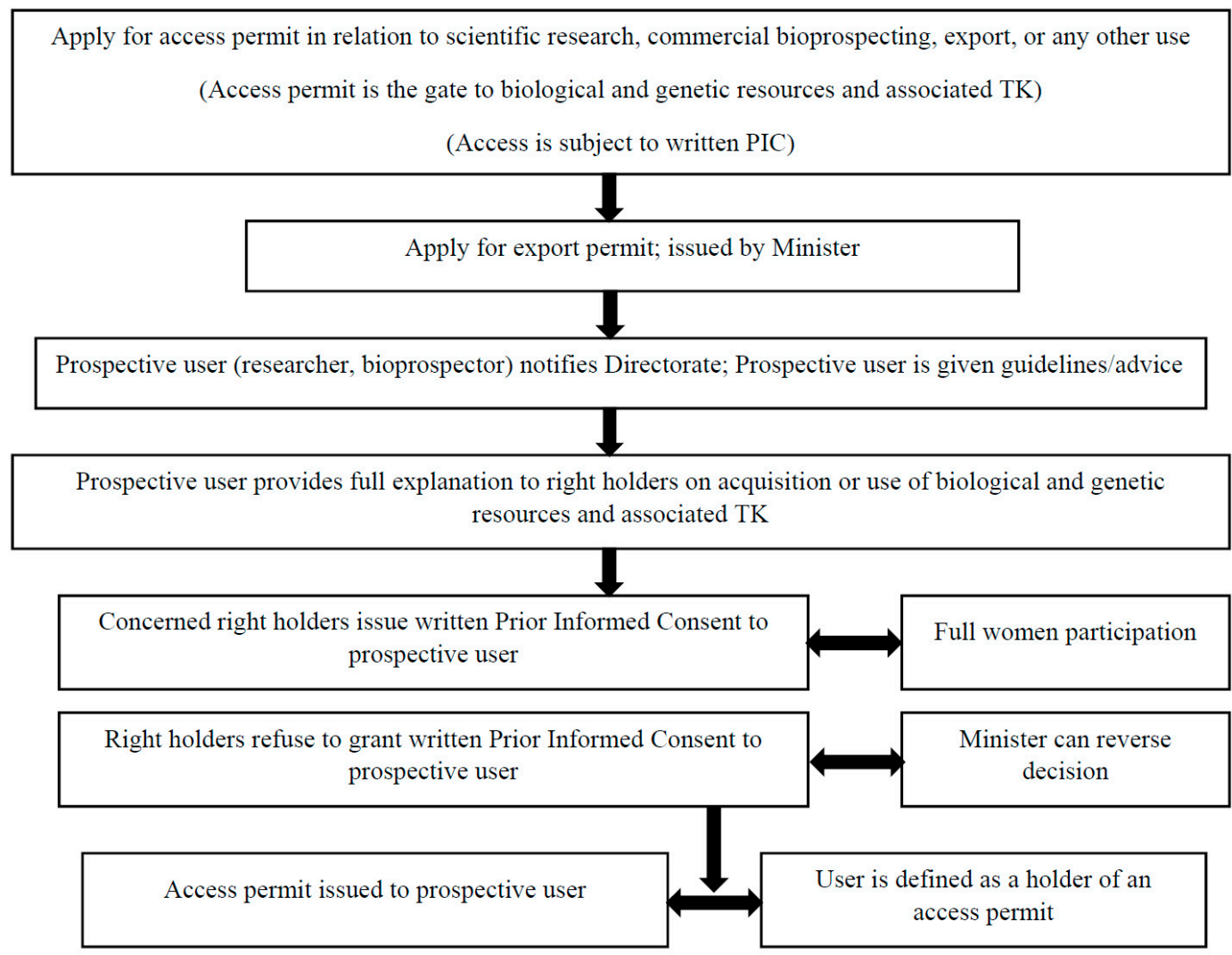

Export permit for export of biological or genetic resources or associated TK; issued by the Ministry

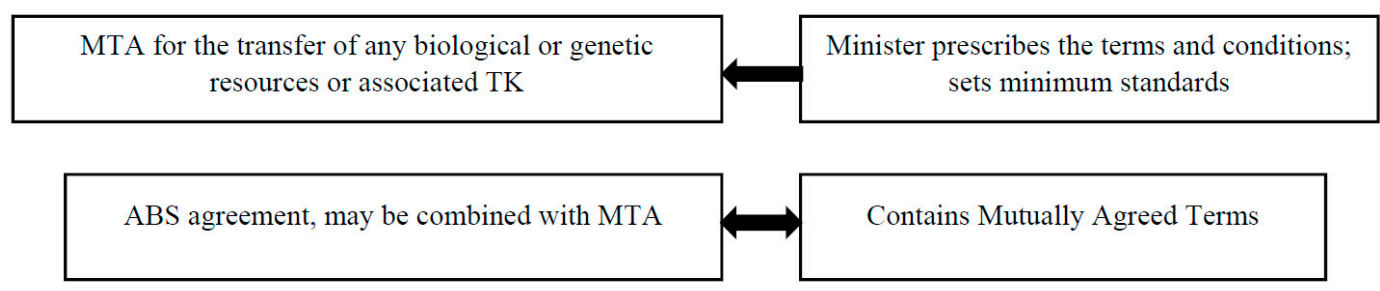

A person may not collect/move any bioresources or acquire associated TK without first obtaining access and export permit and MTA

Monetary and non-monetary benefits accrue to right holders

Figure 1. Machinery for ABS (access and benefit-sharing) processes and permits in Namibia's law on Access to Biological and Genetic Resources and Associated Traditional Knowledge Act of 2017. 
Therefore, this paper traces the evolution of Namibia's ABS law within the context of various international agreements on ABS, national policy and institutional structures on environmental management and bioprospecting, and current perspectives or complexities in the country's post-Apartheid bio-economy where inequitable sharing of benefits from phyto-trade and putative cases of biopiracy serve as key exemplars. Posteriorly, the paper provides personal critical views of the authors and unpicks the salient features of Namibia's 2017 ABS law with special reference to some of the key sticking points and challenges. Points of convergence and departure between the Namibian ABS law and counterpart legislation in neighbouring South Africa are discussed. By presenting a bird's eye view of the various international legal frameworks, regional plus local institutional contexts, and economic or ecological contestations that morphed into Namibia's Access to Biological and Genetic Resources and Associated TK Act of 2017, the paper casts the evolution and existing configuration of Namibia's ABS Act into a more critical and broader public space. This discourse is significant because it impacts and enriches stakeholder buy-in, public awareness, and enforcement, as well as future amendments.

\section{International Agreements on ABS}

Biodiversity-rich developing countries are resentful of the technology-rich countries' centuries of colonialism and the uncompensated export of genetic material and TK; hence, provider countries want to address these injustices and prevent further misappropriation of their resources by users [25]. Biodiversity-rich and provider-countries seek out regulations to compel bioprospectors and users to share with local communities in provider-nations economic benefits emanating from the use of their genetic resources and associated TK [26]. Developing country governments have pressed for the protection of genetic resources and TK in the form of internationally recognized IP rights. However, while the issue of protecting genetic resources and TK elicited public sympathy, meaningful international consensus was difficult to achieve [14].

Adoption of the United Nations Convention on Biological Diversity (CBD) was the first step toward the fair and equitable sharing of benefits from the utilization of genetic resources. The text of the CBD was adopted on 22 May during the Conference for the Adoption of the Agreed Text of the Convention on Biological Diversity in Nairobi. The CBD was opened for signature at the Earth Summit in Rio de Janeiro on 5 June 1992 and entered into force on 29 December 1993. In common parlance, ABS means that granting permits to obtain genetic resources must be subject to legal instruments and provisos of fair and equitable apportioning of the monetary profits and non-monetary gains arising out of the use of such bioresources [27]. Genetic resources are defined in the CBD as 'genetic material of actual or potential value' and constitute a subset of 'biological resources' [28]. The CBD is an international treaty that commits States to conserving biological diversity, using biological resources sustainably, and fairly and equitably sharing benefits derived from the use of genetic resources. Article 8 (j) of the CBD states that signatories to the CBD are to respect, preserve, and maintain the knowledge, practices, and innovations of traditional and local communities [29].

Benefit sharing as envisioned by the CBD was until recently a relatively new inkling in international law [30]. Within the context of non-human biological resources, the CBD sets out commitments for the conservation of biodiversity and its sustainable use by ensuring that its custodians are adequately rewarded for its conservation. Prior to the adoption of the CBD, access to biological resources was frequently regarded as a free-for-all affair [30]. Bioprospectors were able to take resources out of their natural habitats and develop commercial products without sharing benefits with states or local communities.

Namibia signed the CBD in 1992. In 1993, the CBD came into force and promulgated ABS mechanisms (Article 15) through which users would give the provider countries (right holders) fair and equitable benefits, including technology transfer. In lieu of benefits, a provider would facilitate access to biological and genetic resources. Namibia ratified the CBD in 1997 [31]. One of the three objectives of the CBD is the fair and equitable sharing of benefits arising out of the utilization of 
biological and genetic resources. The CBD also addresses TK of the local communities associated with the bioresources. Unfortunately, the CBD has been largely dormant in putting the kibosh on biopiracy and misappropriation of ethnobiological and genetic resources and associated TK [24,32].

Between 1997 and 2001, African countries formulated the African Model Law, which served as a holistic framework for African Union (AU) Member States to domesticate ABS legislation in compliance with international commitments emanating from the CBD, the World Trade Organization (WTO) Agreement on Trade Related Aspects of IP Rights (TRIPs Agreement), and the International Undertaking on Plant Genetic Resources for Food and Agriculture [33]. Principal among these concerns was the requirement by WTO's TRIPs Agreement for Member States to adopt patents, sui generis legislation, or a combination of both for the protection of new varieties of plants. AU Member States envisaged that patents or other forms of IP rights (IPRs) over living organisms would negatively impact communal livelihoods in Africa. The African Model Law was not a real law or agreement, but rather an information package that could be used in drafting national laws [31].

Perhaps one of the most significant problems in current international trade discussions is the contradiction between the CBD, which recognizes the sovereign rights of States (and local communities) over their biological diversity, and TRIPs, which confers monopoly rights through IPRs [34]. A contradiction between CBD and TRIPS emanates, to some extent, from the fact that the TRIPs Agreement does not require prior informed consent (PIC), benefit-sharing, and disclosure of the country of origin of the biological material of the patent claim [35]. Moreover, because the $\mathrm{CBD}$ recognized the role of local communities in the conservation of biodiversity, there were genuine apprehensions that granting exclusive individual and corporate rights over life forms would create conflict between the TRIPs Agreement and the CBD [33]. By tackling the question of property rights and farmers' rights from the perspective of the community, the African Model Law established a legal framework for access to biodiversity, benefit sharing, and IP that gratified the needs of African States; it did so through balancing the monopoly rights of breeders against the rights of indigenous communities [34].

The Bonn Guidelines on Access to Genetic Resources and the Fair and Equitable Sharing of Benefits Arising out of their Utilization identified steps in the ABS process and emphasized the obligation on the part of users to obtain PIC from providers of genetic resources and associated TK [28]. In 2002, the Bonn Guidelines were adopted by the Sixth meeting of the COP-CBD (Conference of the Parties to the Convention on Biological Diversity) in The Hague. Developed as part of the CBD efforts to implement the third objective of the Convention, the Bonn Guidelines are voluntary in nature and cannot be considered as an international agreement. However, the voluntary Bonn Guidelines stipulate a suite of requirements for Mutually Agreed Terms (MAT), roles and responsibilities of users and providers, the significance of involving all stakeholders, including women, elements of incentives, accountability, means for verification and dispute settlement, elements of a Material Transfer Agreement (MTA), and a framework of both monetary and non-monetary benefits [28]. At the World Summit on Sustainable Development in 2002, developing country governments, particularly the Like-Minded Group of Mega-Diverse Countries, called for a legally binding international regime on access and benefit sharing in relation to genetic resources and TK [17].

Then, the International Treaty on Plant Genetic Resources for Food and Agriculture (ITPGRFA) came into force in June 2004 [31]. The objectives of ITPGRFA are the conservation and sustainable use of plant genetic resources for food and agriculture and the fair and equitable sharing of the benefits arising out of their use, in harmony with the CBD, for sustainable agriculture and food security [36]. The aims of the ITPGRFA are quite frankly the same as those of the CBD, except that they are specific to plant genetic resources for food and agriculture (PGRFA). ITPGRFA set a system for access to PGRFA, while access to other genetic resources, for example, chemical and pharmaceutical uses, is negotiated bilaterally in accordance with national ABS policies in the context of the CBD [31].

Popularly known as COP 10, the Conference of the Parties to the CBD in October 2010 adopted the Nagoya Protocol (NP) on Access to Genetic Resources and the Fair and Equitable Sharing of Benefits 
Arising from their Utilization [37]. The spirit of the NP is to regulate the utilization of genetic resources and associated TK for commercial and research purposes by requiring users of these resources to share the benefits with the provider countries or communities [38]. The $2010 \mathrm{NP}$, an adjuvant, but principal, ingredient of the CBD, came into legal force on 12 October 2014, providing for a more transparent and operative legal framework for fair and equitable sharing of benefits arising from the utilization of genetic resources. The NP also sets out obligations for parties to establish and ensure compliance with PIC and MAT in their domestic ABS legislations.

In 2011, Namibia submitted a letter to the CBD secretariat signaling the country's intent to sign and ratify the NP [39]. In May 2014, Namibia acceded to the NP on ABS. On 11 February 2015, Namibia became party to the Swakopmund Protocol on the Protection of Traditional Knowledge and Expressions of Folklore within the Framework of the African Regional Intellectual Property Organization (ARIPO). Other signatories to the Swakopmund Protocol are Gambia, Malawi, Rwanda, Zambia, and Zimbabwe. Summarily, the two main objectives of the Swakopmund Protocol are to protect TK holders against any infringement of their rights, and to guard expressions of folklore against misappropriation, misuse, and unlawful exploitation beyond their traditional context [40]. In the main, Namibia's enactment of the 2017 law on Access to Biological and Genetic Resources and Associated TK is a major discharge of the country's international obligations under the CBD, NP, ITPGRFA, the Swakopmund Protocol, the African Model law, and ARIPO.

\section{Local Institutional Structures for Establishing ABS in Namibia}

The blueprint for Namibia's 2017 law on Access to Biological and Genetic Resources and Associated TK is Article 95(1) of the Namibian constitution, which obliges the government to adopt policies aimed at the maintenance of ecosystems, essential ecological processes, and biodiversity, and the utilization of living natural resources on a sustainable basis for the benefit of all Namibians, both at present and in the future [41]. Article 91(c) also stipulates the functions of the Ombudsman: “... to investigate complaints concerning the over-utilization of living natural resources, the irrational exploitation of non-renewable resources, the degradation and destruction of ecosystems and failure to protect the beauty and character of Namibia." In line with these constitutional obligations, a national programme for plant genetic resources was established in 1990 [42]. These provisions tally with the CBD's goals of conservation and sustainable use of local biodiversity [43].

In 1994, the Namibian Biodiversity Programme was formed, and an inaugural meeting of the bio-trade working group took place in 1998 [44]. A public consultative process jointly spearheaded by the Ministries of Environment and Agriculture was tasked to develop a policy on access to genetic resources and associated TK in 1999 [39]. In April 2000, the Indigenous Fruit Task Team (IFTT) was formed. The aim of the IFTT was to build a coordinated approach and strategy for the implementation of an economically sustainable promotion of indigenous fruits in Namibia. IFTT was converted into the Indigenous Plant Task Team (IPTT) in May 2003 [39].

A government-mandated and multi-stakeholder roundtable, the IPTT is chaired by the National Botanical Research Institute (NBRI). Its objective is to advance the sustainable utilization of Namibia's TK-based plant resources for greater household food security, income generation, employment, resilient livelihoods, and agro-industrial processing. The IPTT also coordinates efforts to create value chains for traditional natural products [45]. The IPTT adopts a pipeline approach in which TK-based resources with product development potential are prioritized [46,47]. To encourage the development of TK-based products, IPTT gives support to local community resource owners, TK holders, researchers, and academics. Guided by a strategic action plan, the IPTT also identifies potential technical partners to support research and product development of TK-based products [47].

A feasibility study to assess ABS in Namibia was concluded in February 2007. The study evaluated the legal, policy, institutional, and commercial dimensions of ABS in relation to international and national frameworks, including research and commercial utilization of genetic resources [48]. In September 2007, a directive was issued by the Namibian government to establish an Interim 
Bioprospecting Committee [49,50]. The mandate of the Interim Bioprospecting Committee was to vet bioprospecting applications to ensure the granting of PIC by local communities, issue bioprospecting permits, and set conditions for ABS agreements [31]. Prior to the 2017 law on Access to Biological and Genetic Resources and Associated TK, the Interim Bioprospecting Committee was the competent national authority. It relied on the law of contract to grant bioprospectors legitimate access to genetic resources and associated TK [46].

Between 2001 and 2010, ABS issues were addressed under the aegis of the first national biodiversity strategy and action plan, jointly funded by the Global Environment Facility, United Nations Environment Programme, and the governments of Namibia and Germany. Dubbed the strategic plan of action for sustainable development through biodiversity conservation [51], some of the programmes were to strengthen, promote, and control bioprospecting and bio-trade activities to generate sustainable benefits for citizens; demonstrate and promote the role of TK in biodiversity conservation and sustainable resource management; and establish opportunities for local communities to share their TK with other parties. Namibia plans to implement the second national biodiversity strategy and action plan in 2013-2022 at an estimated cost of 500 million Namibian dollars (N\$).

Due to the legacy of Apartheid, Namibia's TK is often dismissed as being unscientific and remote to the country's economic development. Yet, according to Jauhiainen and Hooli [52], a TK-based innovation system can enhance the comparative advantage of Namibia, facilitate participatory development processes, and foster socioeconomic resilience of local communities. To reinforce TK-based innovation in Namibia's economy, the National Commission on Research Science and Technology (NCRST) is formulating a national policy on Indigenous Knowledge Systems (IKS). A seeming caricature of South Africa's national IKS policy, the Namibian IKS policy is still in its twilight, but the latter inter alia commits to the grandeur of ABS agreements and equity through redress.

Namibia's IKS policy speaks to the management of TK resources through eight government ministries: Ministry of Environment and Tourism; Ministry of Higher Education, Training, and Innovation; Ministry of Health and Social Services; Ministry of Agriculture, Water, and Forestry; Ministry of Industrialization, Trade, and SME (Small Medium Enterprises) Development; Ministry of Education, Arts, and Culture; Ministry of Fisheries and Marine Resources; and Ministry of Information and Communications Technology. In addition, the policy aims to safeguard TK infrastructure through institutions, such as the National Indigenous Knowledge Council, National Planning Commission, Namibia Traditional Authorities, Business and Intellectual Property Authority, the private sector, and Non-Governmental Organizations (NGOs).

The national IKS policy is being aligned to several international agreements: CBD, NP, ITPGRFA, the Convention on the Protection and Promotion of the Diversity of Cultural Expressions, UNESCO (The United Nations Educational, Scientific and Cultural Organization) Convention for the Safeguarding of Intangible Cultural Heritage, WIPO Internet Treaties of 1996, Model Law for African States on Access to Information, the Swakopmund Protocol, and the SADC Protocol on Science, Technology, and Innovation. At the domestic level, the national IKS policy will be aligned to the Namibian Constitution; Research Science and Technology Act, 2004; Biosafety Act no. 7 of 2006; Traditional Health Practitioners Bill; National Heritage Act No. 24 of 2004; the Namibian Copyright and Neighbouring Rights Protection Act no. 6 of 1994; Business and Intellectual Property Authority Act of 2016; and the Access to Biological and Genetic Resources and Associated Traditional Knowledge Act, 2017.

On the whole, Namibia's enactment of the 2017 law on Access to Biological and Genetic Resources and Associated TK is rooted in the country's constitution, national programme for plant genetic resources, bio-trade working group of the Namibian Biodiversity Programme, IPTT, Interim Bioprospecting Committee, recommendations from the 2007 feasibility study of Namibia's ABS, national biodiversity strategy and action plans, and the incipient national IKS policy, which acknowledges that a TK-based innovation system is a critical pillar of the Namibian nation and economy. 


\section{Commercial Value of Genetic Resources in Namibia: Lessons Learnt from the Past}

The legal bio-economy contributes about 4.5\% to Namibia's Gross Domestic Product (GDP). This figure may increase to 7\% by 2022 [46]. However, Namibia's bio-economy enriches only a few people, especially exporters, at the expense of local communities. In this section, we posit that the evolution of the Access to Biological and Genetic Resources and Associated Traditional Knowledge Act of 2017 was partly premised on the imperatives of the country's inequitable bio-economy. We therefore postulate that this law inexorably originates against a backdrop of an inequitable bio-economy. The general narrative for ABS legislation in Namibia is imprinted in the country's collective conscience, characterized by unfair sharing of monetary benefits from the largely illicit green economy. We specifically postulate that the lack of tangible benefits from bioprospecting, inequitable monetary benefits from international sales of Hoodia and Devil's claw (Harpagophytum procumbens and H. zeyheri), and putative cases of biopiracy were harbingers of the Access to Biological and Genetic Resources and Associated Traditional Knowledge Act of 2017. The government's predilection for ABS and the fundamentals of the Act are also driven by economical, ecological, and political power contestations that inform current conversations around access to local communities' genetic resources and TK.

\subsection{Hoodia and the San People}

At the international level, tensions about the commodification of TK are illustrated by the commercialization of Hoodia gordonii, a succulent perennial plant that has been used by the San people for thousands of years. According to Wynberg and Chennells [53], the San people are the oldest human inhabitants of Southern Africa. The arrival of Bantu pastoralists and agriculturalists (in the last 2500-500 years) and white settlers (in the last 300 years) resulted in the assimilation, subordination, and maltreatment of the San people [54]. After centuries of genocide and marginalization by colonialists, the population of these nomadic hunter-gatherers reduced from 300,000 to only about 100,000 San now living in Botswana (46,000), Namibia (38,000), Angola (7000), South Africa (6000), Zambia (500), and Zimbabwe (500) [55]. Their current lives are characterized by penury, yet they still possess critical TK about their local environment and biodiversity, especially Hoodia, which is endemic to the Kalahari Desert of Botswana, Namibia, and South Africa.

Contrary to many reports, $H$. gordonii is not a cactus, but a member of the Asclepiadaceae, the milkweed family [55]. To quench thirst and suppress appetite during their long hunting trips, the San of the Kalahari Desert chew Hoodia (Ghaap), also used as a remedy for abdominal cramps, tuberculosis, hemorrhoids, indigestion, hypertension, and diabetes [56]. The San also use Hoodia to improve virility and overcome hangovers [56]. Use of Hoodia by the San people was first recorded by the botanist, Francis Masson, in 1796 [57]. However, the first recorded use of Hoodia for suppressing appetite, based on the San people's TK, was documented in 1936. Based on historical publications, the Council for scientific and Industrial Research (CSIR) became aware of the traditional medico-botanical uses of Hoodia by the San, and in 1963, included Hoodia in a project on edible wild plants [58]. In 1963, the National Food Research Institute at the CSIR, Pretoria, South Africa, investigated more than a thousand species of indigenous plants that were used as food, among them the Hoodia species [59].

In a reactivation of the project motivated by Prof. P.S. Steyn in 1986, Hoodia was investigated at CSIR's National Chemical Research Laboratory. CSIR accounts for about $10 \%$ of the entire African R\&D (Research and Development) budget [35]. Based on the San people's TK of the appetite suppressant properties of Hoodia [55], the CSIR set out to isolate the active ingredients from the plant, which it did not conclude due to limitations in technology [58]. Amusan [60] posited that research on Hoodia was inspired by the need to develop hunger suppressants for strengthening South Africa's foot soldiers as part of Apartheid's regional destabilization policy. Nonetheless, the initial experiments on mice were meant to test the thirst quenching properties as reported by Pappe in 1862 and Laidler in 1928; these experiments demonstrated the appetite-suppressant activity of the Hoodia extracts [59]. After the 
acquisition of a nuclear magnetic resonance (NMR) spectroscopy machine in 1986, CSIR revived its interest in isolating Hoodia's appetite suppressant ingredients [35]. NMR made it possible to fingerprint plant chemicals.

CSIR made a breakthrough when Fanie van Heerden and colleagues elucidated the appetite-suppressant principle, P57A53 [61], commonly known as P57 [62]. The active appetite suppressant ingredient was identified as a triglycoside of $12 \beta$-tigloyloxy-14 $\beta$-hydroxypregn-5-en-20 -one, a minor component of the plant extract [59]. In 1995, CSIR filed an application for a patent for the use of P57, without the knowledge and consent of the San [17]. The South African Patent Office granted CSIR patent No. 198.3170, which covers both the process and the product [55]. Used to develop slimming tablets, P57 would in essence tap into the US\$3 billion market for anti-obesity dietary products in the United States of America (USA) [35]. In 1998, CSIR granted a license agreement for the further development and commercialization of the patent to Phytopharm [17], a United Kingdom-based herbal company.

Phytopharm was granted exclusive worldwide rights to manufacture and market Hoodia-related products and to exploit any other part of CSIR's IPRs relating to Hoodia [35]. In December 2001, Phytopharm reported the successful completion of phase IIa/third-stage proof of principle clinical trials. In July 2002, after Phytopharm developed the P57 drug lead to a more advanced stage, and it sold the patent to Pfizer for US\$32 billion to develop and market slimming pills [35]. In July 2003, Pfizer merged with Pharmacia and closed its Natureceuticals Group, which was responsible for the development of P57. The new conglomerate ceased the clinical development of P57-based drugs and returned the licensing rights to Phytopharm, which was at liberty to license P57 to other firms.

To tap into the global anti-obesity market, Phytopharm in 2004 entered into a joint development agreement with the consumer multinational company, Unilever, which produced a P57-based weight management product, licensed in the European Union as a functional food called SlimFast shake [53]. In California, USA, Hoodia was sold as Liquid Hoodia Extreme, DEX-L10 Hoodia gordonii, Maximum Strength Hoodia Rapid-Gels, and H57 Hoodia [63]. The burgeoning global market for Hoodia instigated many fake Hoodia products, some selling for as high as US\$200 per kg [17]. Unilever withdrew four years later due to safety and efficacy concerns. Phytopharm later left the functional food industry and returned the patent to CSIR at a token fee. The development of an anti-obesity drug from a traditional remedy used by Africa's San people suffered a setback after Phytopharm abandoned its research, leaving prospects of a commercial product uncertain [64]. Even so, Phytopharm earned over US\$10 million while the San people, the originators of the TK, languished without any economic benefits [65].

Until a June 2001 newspaper report, the San authorities were unaware that their TK of Hoodia had commercial applications, and that this TK had led to research, scientific validation, and the filing of international patents by the CSIR [35]. The San were also excluded from lucrative deals during the development of P57-based slimming drugs and functional foods. This seemed to change on 1 February 2002 when a Memorandum of Understanding was signed between the CSIR and the South African San Council, recognizing the San as the originators of the TK about medicinal properties of Hoodia. In March 2003, following intractable negotiations, a BSA was signed between the CSIR and the South African San Council [66].

Wynberg [35] reported that in terms of the BSA, the San would receive $6 \%$ of royalties and $8 \%$ of the milestone income received by the CSIR from Phytopharm. In the event of successful commercialization, these funds would be payable into a Trust set up jointly by the CSIR and the South African San Council to raise the standard of living and well-being of the San peoples of Southern Africa $[53,54]$. Provision 4 of the BSA specified that any IP arising from the TK of Hoodia and patents for P57 was vested exclusively with the CSIR [55]. Provision 6 included an undertaking and warranty by the San that they would not assist or enter into an agreement with any third party for the development, research, and exploitation of any competing products or patents; and that they would not contest the enforceability or validity of the CSIR's right, title, and interest in the P57 patent and related products [58]. 
While Phytopharm earned tens of millions of dollars through R\&D funding and the sale of licensing rights, the San received about US\$73,000 over a seven-year period (since 2003) from the agreement with CSIR and were reportedly happy with the arrangement [53,54,64]. By 2007, only US $\$ 100,000$ had been received by the San-Hoodia Trust [17]. For many years, the case of Hoodia and the San reminded stakeholders in Namibia about the existence of biopiracy and frustrations of benefit-sharing; that it is possible for foreign companies to keep making money from genetic resources through $R \& D$ while the customary owners of the resources and associated TK used during bioprospecting languish without benefits [53-55,66].

Given the complex nature of ABS issues related to Hoodia, authorities in Namibia were perceptive that the classic method of patenting may not easily be applied to the development of phytomedicines because R\&D 'innovators' may not easily remit benefits to TK holders [67]. The case of Hoodia illustrates that standard patents and ABS agreements can be unhelpful to TK holders. According to Nijar [68], since the Hoodia bioresource and associated TK are spread among indigenous San communities residing in Namibia, South Africa, and Botswana; this situation requires regional strategies, probably through a clearing house mechanism (and this is in accordance with obligations of parties to cooperate in transboundary situations, Article 11 of the NP) to ensure a participatory process among all TK holders to secure benefits.

Overall, the case of Hoodia reveals eight major challenges of ABS legislation [35]: Not all TK holders can access benefits; non-San TK holders from the Damara/Nama and Topnaar were excluded from ABS agreements; paltry benefits (the San were entitled to a paltry $0.03-1.2 \%$ of royalties after net sales); restrictive ABS regimes (San were prevented from entering into future agreements, no matter how lucrative); importance to negotiate for non-monetary benefits (the agreements were silent on non-monetary benefits); lack of transparency by companies (profits may have been concealed into expenditure for research and development; thus, instead of declaring US $\$ 400-800$ million, only US\$32 million was declared); San people in Namibia and Botswana did not receive equitable benefits compared to their counterparts in South Africa- this raises the need for mechanisms to implement transnational and regional ABS instruments; lack of appropriate positive protection (absence of co-owned patents between San TK holders and CSIR, and absence of sui generis legislation) and defensive protection (TK database, and 'no patents' on life ABS models for developing non-patented herbal medicines); and the need to build trust, obtain PIC, sign benefit-sharing agreement, and the importance of involving the local community and government right from the start.

Vermeylen [69] lamented that Hoodia was patented without the PIC of the San people. Although a BSA was belatedly signed, the case of Hoodia underlines a serious weakness in the CBD as it demonstrates how significant inequities in knowledge and power between Indigenous peoples and companies can result in definitions that are predominantly shaped by the latter, because the CBD falls short of defining fairness or equity [69]. In Namibia, as in many African countries, the case resulted in heightened interest about the importance of protecting TK and ensuring that holders of such TK receive fair compensation [53]. In constructing frameworks for protecting TK, bottom-up approaches that include the establishment of local knowledge innovation zones patterned after the successful USA 19th century development strategy may give local communities greater freedom to influence how TK can contribute to the development of technological capacity in local communities [70]. Although benefit-sharing is not a substitute for regional governments' responsibility to develop impoverished San communities [66], in retrospect, the case of Hoodia and the San may have weighed heavily on the Namibian government's collective conscience to enact the 2017 law on Access to Biological and Genetic Resources and Associated TK.

\subsection{Colonial Bioprospecting of Devil's Claw: The Case of Harpago Tea}

The first scientific report on the medicinal uses of Devil's claw was probably in 1822 when the plant was first collected and described by colonial scientists in South-West Africa, now Namibia [71]. Yet, it was only in 1907 during the Scramble for Africa that the Germany colonialist, G.H. Mehnert, 
having tapped into the rich vein of the TK of the Khoi and San peoples, would claim the 'discovery' of the medicinal properties of Devil's claw in present-day Namibia [71]. This early colonialist turned bioprospector exported dried Devil's claw tubers to Germany where the material was first studied by B. Zorn at the University of Jena in the 1950s [72]. Thereafter, the analgesic and anti-inflammatory properties of the Devil's claw were recognised by Western medicine. Since then, Namibia's Devil's claw has not retreated from the speculative marketplace of global capital and bio-trade.

In 1962, the Namibian company, Harpago (Pty) Ltd (Windhoek, South Africa), started exporting Devil's claw tubers in large quantities to the German company, Erwin Hagen Naturheilmittel $\mathrm{GmbH}$ [72]. In Germany, the dried tubers of Devil's claw were in the 1960s used as a general blood cleanser, including a bitter tea for treating dyspepsia. Part of an advert of Harpago tea read [71]: "Through the Ages, the black witchdoctors have been familiar with the health-giving effects of Harpago tea. Their secrets have now been discovered by science" (p. 8). On the contrary, innovation of Harpago tea was a typical case of biopiracy of the Namibian Khoi and San peoples' TK of the medicinal properties of the Devil's claw [71].

If Harpago tea was manufactured after the CBD came into force in 1993, Harpago (Pyt) Ltd. would have compensated Khoi and San communities, the right holders of the TK associated with the medicinal properties of Devil's claw. Regrettably, Namibia's Indigenous people have not received any monetary benefits for their TK of the medicinal properties of the Devil's claw used to produce and market Harpago tea. Instead, it is the middlemen and companies who continue to earn huge profits from Devil's claw. Besides, as manufacturers continue to protect their Devil's claw-based herbal drugs through trade secrets and brand names [73], the San and Khoi peoples' rights to their ethnobotanical knowledge of the medicinal properties of Devil's claw have been misappropriated and completely lost because patents on extraction and processing methods were granted to commercial companies in Germany and the United Kingdom [23].

\subsection{Contemporary Trade in Devil's Claw: The Devil Is in the Details}

Known by most local people in Namibia as makakata, Devil's claw tuber extracts contain iridoid glycoside, a harpagoside for the management of degenerative rheumatoid arthritis, osteoarthritis, tendonitis, kidney inflammation, and heart disease [74]. Devil's claw traditionally relieves pain and inflammation, and reduces uric acid levels during gout. Indigenous inhabitants of Namibia mainly use the plant's tubers as an analgesic, health tonic, and remedy for digestive disorders, fever, sores, ulcers, and boils [72]. Kim and Park [75] found that Devil's claw harpagoside activates peroxisome proliferator-activated receptor gamma (PPAR- $\gamma$ ); this confers anti-obesity functions. Devil's claw harpagoside inhibits tumour necrosis factor- $\alpha$-induced mRNA synthesis and protein production of the atherogenic adipokines, including interleukin-6, plasminogen activator inhibitor-1, and adipose-tissue-derived monocyte chemo-attractant protein-1 [75]. These molecular properties partially prevent obesity-induced atherosclerosis by attenuating inflammatory reactions. Devil's claw harpagoside confers weight loss and weight maintenance benefits via loss of appetite [76]. Medicinal applications of Devil's claw are harnessed by multinational pharmaceutical companies without any tangible monetary benefits to the owners of the indigenous knowledge primordially associated with the medicinal properties of the plant in Namibia, the country of origin for most of the Devil's claw used in the world.

Despite the lack of significant economic benefits to local communities, Namibia supplies $95 \%$ of the world's Devil's claw; Botswana and South Africa supply the remainder [77]. Empirical records of trade in Devil's claw go as far back as 1975 when Namibia (then South West Africa) exported about 180 tonnes of plant material to Germany [78]. By 1981, the country exported about 200 tonnes of Devil's claw per year. Exports of the plant tubers were estimated at 600 tonnes in 1998 and 1999, and four years later, Namibia exported in excess of 1000 tonnes per year [78]. Between 1995 and 2002, 17 Namibian exporters sold about 4000 tonnes of dried tubers to various countries [78]. Trade in Devil's claw reached its apogee in 2002 when 1018 tonnes of dried tubers were exported to Germany [79]. 
In that year, sales soared to 30 million Euros as Devil's claw herbal drugs accounted for $74 \%$ of the prescriptions for rheumatism [74]. By 2007, $50 \mathrm{~g}$ of purified Devil's claw extract in tablet form fetched 25 Euros [19].

Namibian export of Devil's claw is estimated at N\$20-30 million per annum [72]. In spite of the good sales of Devil's claw in Europe, middlemen and exporters exploited Namibian harvesters who were ignorant about the commercial prices and intricacies of the market. There are varying and contradictory reports of the actual cash figures that exporters pay local harvesters of Devil's claw. In general, exporters pay Namibian harvesters as low as US\$0.15 per $\mathrm{kg}$ of dried sliced tubers [73]. In exceptional cases, the highest payment is US\$1.20 per $\mathrm{kg}$. Communal harvesters who sell their Devil's claw to middlemen may also receive a paltry $\mathrm{N} \$ 12$ per $\mathrm{kg}$. Local harvesters desperate for cash accept contracts to sell their Devil's claw for US\$10-50 per kg per annum [71]. Buyers pay as little as $\mathrm{N} \$ 0.40$ per $\mathrm{kg}$ of dried tubers to each of the 6000 poverty-stricken harvesters in Nyae Nyae and Okakarara [77]. Wegener [80] reported that Namibian collectors were paid $\mathrm{N} \$ 0.30$ to 0.40 per $\mathrm{kg}$ of dried tubers. In terms of the percentage share of benefits, Namibian harvesters receive less than $0.5 \%$ [78].

Parsimonious European pharmaceutical industries that make humongous profits from the manufacture and sale of Devil's claw products have no ethical corporate conscience to share economic benefits with poor harvesters in Namibia. Speaking at a symposium on the Devil's claw in 2001, Namibia's founding President Dr. Sam Nujoma forewarned [50]:

"I believe that while scientific research is necessary to improve the way in which our natural resources are exploited; our people must not be completely disowned of resources that they have possessed for generations. It will be a sad day when the medicinal formulas of Devil's claw are patented by big pharmaceutical companies and thereby become depleted and unavailable to the natural owners of the resource". (p. 9)

Yet, as Nujoma had dreaded, the Namibian owners of the plant and ethnomedicinal knowledge were neither addressed through patent negotiations nor BSAs even in the aftermath of the enormous commercial success of Devil's claw in Germany where it became the third most frequently used herbal drug of all time. Indigenous communities in Namibia have been dispossessed of their rights over Devil's claw and associated ethnomedicinal knowledge in four main ways [71]: Through conquest by immigrating Bantu-speaking people; through German colonization; by South African occupation and Apartheid settlement; and by physically and economically more powerful cattle farmers who now own land in the areas where Devil's claw grows and is harvested.

However, every cloud has a silver lining, and since 1999, the Sustainably Harvested Devil's Claw Project (SHDCP) has helped secure better monetary benefits for Namibia's San (Ju/'hoansi and Nharo) harvesters [71]. A total of 240 harvesters in the SHDCP earned N\$67,108.80 [71]. In the year 2000 , another 162 harvesters sold $4740.6 \mathrm{~kg}$ through the SHDCP, earning N\$55,971. SHDCP increased harvesters' earnings from $\mathrm{N} \$ 8$ per $\mathrm{kg}$ to $\mathrm{N} \$ 12$ per $\mathrm{kg}$ for sliced dried tubers of Devil's claw [71]. In terms of overall export trade, this symbolic increase in harvesters' earnings attributable to the work of SHDCP is still insignificant. A 2014 Millennium Challenge Account Namibia report [81] claimed that consortia of 19 harvesters that sold 104 tonnes of Devil's claw earned N\$2.4 million; each of the 1494 harvesters earned $\mathrm{N} \$ 1660.43$.

It is evident that ABS issues in respect to Namibia's Devil's claw are disconcerting, and the devil is in the details. The inequitable sharing of benefits from trade in Devil's claw demonstrates that if there is a motive behind the 2017 ABS law; it must originate in the high octane battle between economic inclusivity and exclusivity. At the crux of this 2017 law on Access to Biological and Genetic Resources and Associated TK is more than regulation of bio-trade. It is about creating a moral high ground for economic justice, inclusiveness, and equality in the sharing of benefits, especially from trade in Devil's claw. 


\subsection{Trade in Other Indigenous Plant-Based Products}

Apart from Devil's claw, several other Namibian Indigenous plants are sold for their commercial value and medicinal applications [23]: Marula fruit (Sclerocarya birrea), succulents, watermelon (Citrillus lanatus), nara fruit (Acanthosicyos horridus), monkey oranges (Strychnoss species), and manketti nut (Schinziophyton rautanenii). In 2005, Indigenous plant products contributed N\$100 million (US\$13.7 million) to the country's economy; this accounted for almost $0.15 \%$ of total GDP [46]. In 2009, over 401,728 kg of selected indigenous plant products, including Devil's claw, Hoodia gordonii, Kalahari melon seed oil, marula oil, Ximenia americana oil, and Commiphora wildii resin, estimated at $\mathrm{N} \$ 22$ million were exported from Namibia [77].

Commiphora wildii (Namibian myrrh) is mainly found in remote parts of the Kunene Region where it is locally called Omumbiri. The plant produces a resin traditionally used to make body perfume by the Himba people. A single $C$. wildii plant produces an average of $85 \mathrm{~mL}$ of resin [82]. Commercial harvesting of $C$. wildii resin began in 2007 when a total of five tonnes worth US $\$ 50,000$ were harvested by 319 conservancy members [81]. Harvesters collectively earned a total of $N \$ 250,000$ between 2007 and 2008. About 50 tonnes of resin are now harvested every year in five conservancies: Puros, Orupembe, Marienfluss, Sanitatas, and Okondjombo [83]. Kunene Conservancy Indigenous Natural Products Trust owns the Opuwo Processing Facility (OPF), which distils the essential oil from C. wildii resin. OPF sells the essential oil at a price of $\mathrm{N} \$ 5000$ per $\mathrm{kg}$ to companies in Namibia, South Africa, France, and Germany [81]. In 2008, samples of the resin and the essential oil were taken to the In-Cosmetics Trade Fair in Paris [83].

The Himba are the right holders of the Indigenous knowledge used to make the essential oil from C. wildii resin [81-83]. In April 2010, the local people under the aegis of the Kunene Commiphora Conservancies Association, a consortium of five conservancies, entered into the first-ever ABS agreement with Afriplex Ltd. (Paarl, South Africa), a South African company. Harvesters were paid $\mathrm{N} \$ 50$ per $\mathrm{kg}$ of gum, and during the three to four months of the harvesting season, each harvester earned between $\mathrm{N} \$ 1000-5000$ (average $\mathrm{N} \$ 1500$ ). Another example of an ABS agreement in Namibia is between the Eudafano Women's Cooperative and The Body Shop [31]. In this agreement, the local people are the preferential suppliers of marula oil to the company. The producers are co-owners of a patent on a type of marula oil with enhanced antioxidant properties.

In the framework of the marula project, selective breeding is also carried out to identify and multiply sweeter varieties. Also, agronomic work is done to enhance the management practices of S. birrea plants. Harvesting and sale of mopane worms (Imbrasia belina) is common in northern Namibia [84]. Mopane (Colophospermum mopane) seeds are harvested in Sesfontein, Anabeb, Otjiu-West, Okongoro, and Orupupa conservancies, and harvesters earn N\$2.50 per kg [81]. A total of 11,223 kg of dried Hoodia powder had a market value of N\$700,000 in 2011; and 572,250 Hoodia capsules worth $\mathrm{N} \$ 458,528$ were exported mainly to New Zealand and Europe [81]. About 70 tonnes of X. americana kernels were harvested in six years, earning $\mathrm{N} \$ 626$ per harvester per year. Nara melons, sold at a price of $\mathrm{N} \$ 22$ per $\mathrm{kg}$, fetched up to $\mathrm{N} \$ 2000$ per harvester.

Many plant harvesters still earn less than $2-3 \%$ of the real retail value of the price of the final products whose raw plant materials they supply [46]. There are huge disparities between the earnings of foreign exporters and Namibian communities/harvesters of the Indigenous plant products. These disproportions offer a real-time glimpse into the inner economic frustrations of the local people whirling in the lack of monetary benefits from herbal products derived from the use of their ethnomedicinal knowledge. The inequalities are also a stark reminder that in an unregulated environment, Namibia's phyto-trade and bioprospecting remain Hobbesian enterprises, and access to ethnomedicinal resources and ABS largely present a poignant nexus in the country. Claims by UNEP [46] that traders in Indigenous plants are likely to gain premium prices from export markets, such as the European Union, are incorrect and ill-informed by current data on the ground. What is correct, though, is that robust ABS policy support and investment are needed to derive equitable, secure, and higher sustainable development returns from phyto-trade. 
With more than 687 endemic plant species (275 of these, including the famous Welwitschia mirabilis, are endemic to the Namib Desert), wild plants in Namibia represent considerable genetic diversity and development potential, especially in the fields of agriculture and pharmaceuticals [85]. Trade in Indigenous plants forms a hidden bio-economy that could support the livelihoods of many rural households $[19,86]$. However, Namibia remains a country with high levels of poverty at 55.8\% [87]. To reduce income poverty and inequality, biodiversity and phyto-trade are potentially powerful engines for sustainable and pro-poor socioeconomic development [88]. However, phyto-trade will be important in government's efforts to reduce poverty in rural areas unless harvesters and other resource stewards receive a fair share of the retail value of the resources being traded [89]. At the moment, benefits from phyto-trade remain exclusionary, benefiting a few traders and middlemen. Therefore, ABS legislation has found a renewed promise to surmount current economic imbalances associated with phyto-trade.

\subsection{Putative, but Unproven, Cases of Biopiracy}

The International Institute for Environment and Development [89] noted that biopiracy, the appropriation of the knowledge and genetic resources of Indigenous communities without permission or compensation, is a serious shortcoming in Namibia. Some of the putative cases of biopiracy involve pharmaceutical companies extracting and selling snake venom, smuggling of live scorpions, illegal marine bio-prospecting, harvesting of termite queens, and tourists trafficking in lizards [39]. Many traditional leaders believe the lack of laws to enforce ABS agreements has aggravated putative cases of biopiracy in Namibia [89]. For example, a company in Oshakati was accused of buying watermelon (Citrillus lanatus) fruits from which seeds were extracted for sale to cosmetics companies [23]. While it is beyond the scope of this paper to ascertain if this company unethically or unlawfully appropriated the biological materials, ABS activists claim the same company may have 'shortchanged' villagers out of the monetary benefits from the sale of monkey oranges (Strychnoss sp.), manketti nut (Schinziophyton rautanenii), and succulent plants [23].

Another unproven allegation of biopiracy involves a pharmaceutical company that filed for a patent in relation to a chemical substance isolated from a fungus found in the dung of giraffes located near the Namutoni Gate of the Etosha National Park in northern Namibia [90]. The substance was said to have broad spectrum antifungal activity against both human and plant fungal pathogens. Germplasm of Namibian marula trees (S. birrea), whose fruits are used as food and drink supplements by the San and Ovambo people, was taken to Israel and South Africa. Using Indigenous knowledge of local growers in Namibia, it is believed that breeding for improved cultivars of marula trees was done in South Africa, ostensibly without the remittance of monetary benefits to TK holders in Namibia [23]. Again, the authors of this paper do not in any way allege or suggest any impropriety on the part of the said persons or organizations, but these cases have renewed unwarranted fears of biopiracy (though this has not been proved) in Namibia.

Lack of ABS legislation even prompted a bizarre request from an institution in the USA to survey Namibia's entire flora in exchange for a pittance of US\$5000 [23]. The resurrection plant, Myrothamnus flabellifolius, from the Namib Desert is believed to be almost extinct because of putative biopiracy for drought-tolerance genes needed for genetic engineering of drought-tolerant crops [23]. While it is beyond the scope of this paper to state if the above cases fit the definition of biopiracy, some local people and ABS activists point to these few putative cases as a tip of the biopiracy iceberg in Namibia. As Namibia's biological resources continue to enter the speculative marketplace of bio-capital, the country's political leadership has reawakened to the commercial benefits of bioprospecting and bio-trade. In retrospect, many scholars, including Roberts [91], seem to allude to the argument that misappropriation of Namibia's ethnomedicinal plants, for example, could be founded in the oppressive partnership between Western medicine and European colonialism, on the one hand, and racist medical policies during Apartheid, on the other. 


\section{Green Economy as a Driver of ABS Legislation in Namibia}

Although Namibia is a diamondiferous country, biodiversity in general and ethnomedicinal plants in particular are perceived as the country's 'green diamonds' [50]. The green economy if well-regulated could offer a gracious source of income to decrease poverty in rural areas. However, Namibians have to a large extent not benefitted from bioprospecting and commercialization of their ethnobiological resources, mainly because current bio-economic practices are a canonical example of exploitative and manipulative tendencies carried forward from the country's Apartheid past. It is within this prism of economic dispossession that the entry point for ABS legislation is informed by a multiplicity of moral and economic justice imperatives [10]. In other words, due to the lack of benefits from their ethnobiological resources and associated TK, Indigenous Namibians have endured socioeconomic pain. Corollary, the 2017 ABS law comes on the heels of the country's collective understanding that pain is the greatest incentive for change. In a way, enactment of the 2017 law on Access to Biological and Genetic Resources and Associated TK gives meaning to the Namibian government's political commitment to fight inequality in the bio-economy. The law also stokes local communities' resentment of the lack of monetary benefits from bio-trade at a time when the rural poor and peri-urban have-nots are writhing in suppressed fury exacerbated by economic recession.

Namibia is one of the most economically-unequal societies in the world, a legacy inherited from Apartheid. ABS is therefore a subject that cries out for an examination of where the country is heading in terms of achieving economic justice. ABS laws should unequivocally act as a local bulwark against economic injustice even as global demands for ABS laws are becoming more and more insistent. A viable search for ABS legislation in Namibia must crucially begin with a frank admission of post-Apartheid income inequality and market-based conservation. Namibia has many conservancies with plenty of wildlife for tourism. However, there is increasing human-wildlife conflict and citizens are hardly compensated for property damaged by wildlife. As a subtle policy strategy, this ABS law may be the Trojan horse for government to ingeniously whip up pro-establishment emotions in spite of the Ministry of Environment's failure to compensate victims in the face of rampant human-wildlife conflicts. Despite many constraints, even in the face of skepticism from opponents, the prospect to use the 2017 ABS law to bring benefits to local communities remains defiant.

Ecologically, the government should balance phyto-trade with the need for sustainable harvesting. As trade in Devil's claw continues to increase, natural populations of the plant are crushingly annihilated to the extent that Devil's claw was tabled as an endangered species at a Convention on International Trade in Endangered Species meeting [71]. Berg and Gensthaler [92] found that before the year, 2000, there were 1000-2000 plants of Devil's claw per hectare in many areas where the plant grew naturally. Sadly, by the year, 2001, only one plant per hectare was left. To obtain one tonne of dried Devil's claw tubers, harvesters dig up approximately 5000-10,000 wild plants [78]. Millions of plants are harvested annually to meet the annual export target of thousands of tonnes of dried tubers, putting the natural populations of Devil's claw at the risk of biological annihilation [93]. Sustainable harvesting of Devil's claw is difficult to inculcate because, since 1986, many exporters and their agents have been harvesting tubers without obtaining valid permits. While harvesting is only valid from March to October, harvesters dig out the tubers throughout the year. Harvesting permits issued by the Ministry of Environment cost N\$200-500.

Although unfettered collection by commercial harvesters puts ethnomedicinal plant species at the risk of extinction [94], environmental management and conservation are highly prized activities in Namibia. Environmental stewardship includes the role of traditional communities and authorities concerned with the management of the country's natural resources, based on customary norms that controlled access to ethnobiological resources. Local communities use medico-botanical knowledge and direct dependence on their ethnomedicinal plants as the sole and prime basis to undertake conservation more effectively than government agencies, which are remotely linked to the local resources. For this reason, it is critical to align long-term conservation with the short-term needs 
of the local people; by so doing, local community members gain benefits for their participation in conservation [95].

Namibia (article 66 of the constitution) accords co-equal recognition to customary and common laws; as long as they are not in conflict with provisions of the constitution. For example, the Traditional Authorities Act (No. 25 of 2000) empowers the chief or head of that community to ensure that the members of her or his traditional community use the local natural resources in a sustainable manner to conserve the environment and maintain the ecosystem for the benefit of all persons. Thus, Parviainen [96] reported that local communities in Okongo and Kwandu were granted legal rights over the sale of timber. Although local communities and authorities can regulate access to local resources and help limit ethnobiological resource extraction and depletion, traditional autonomy to control ethnobiological resources was curtailed during Apartheid [23], and many years of independence have done little to halt or reverse central government's weakening of traditional authority structures and customary law enforcement over the control of ethnobiological resources in Namibia. New local government structures and new statutory laws have been created, but they seldom buttress traditional autonomy over ethnobiological resources [23].

\section{Analysis of Important Sticking Points in Namibia's Current ABS Law}

In this section, the discussion unpicks significant features of the Namibian ABS law. Specifically, the contextual analysis focusses on the lack of adequate participatory consultations and technical capacity at the local level, the discount of non-commodity and cultural value of TK, defensive versus positive protection, the ambiguous and narrow definition of community, the lack of a clause on confidentiality, and assertions that the new ABS law will negatively impact research in Namibian universities and botanic gardens. A closer look at the contrasts between ABS law in Namibia and South Africa reveals a major limitation for Namibia; namely, while South African law differentiates between commercial and non-commercial research, Namibian law does not.

\subsection{Lack of Participatory Consultations and Technical Capacity at the Local Level}

Brink [31] reported that many Namibian Non-Governmental Organizations (NGOs) decried their lack of consultations by the Ministry of Environment and Tourism during the development of the 2017 ABS legislation. According to the NGOs, traditional leaders consulted in the process of drafting the new law did not comprehend substantive issues. Since Namibia faces a perceptible gulf between law development and implementation, the capacity on the ground to implement this ABS law, as is the case with other government policies, is quite limited. The current ABS law also faces technical challenges as it does not adequately address issues of safety and quality to satisfy EU regulations and requirements [97]. For example, EU companies require a complete safety dossier before considering the importation of Commiphora products from Namibia. To develop this dossier is expensive and requires technical skills and specialized equipment that are not available in local communities in Namibia. Adhering to international safety and quality protocols, not the sharing of benefits, is perhaps the greatest obstacle to the export of Indigenous plant products from Namibia.

\subsection{Importance of Non-Commodity and Cultural Value of TK}

There are contentions that since the current law is an embodiment of the commodification of $\mathrm{TK}$, it demeans TK's rich heritage of cultural, symbolic, and ritual values. By overly emphasizing the commercial and market incentives associated with the TK of ethnomedicinal plants, Namibia's Access to Biological and Genetic Resources and Associated TK Act of 2017 assumes that TK is only valuable when it is sold to the highest bidder and validated by Western scientists. In this sense, the Act lacks Afrosensitivity to African spirituality because it is premised on a Eurocentric and neoliberal praxis, which does not recognize the priceless cultural and symbolic value of African TK [54]. The Act's main interest to protect TK is seemingly rooted in the campaign for social, economic, and ecological 
development of local communities [98], not necessarily the support for the cultural, symbolic, and ritual values of TK.

TK is part of the social capital of the poor. It enables societies to collectively adapt to their environment [99]. TK is the currency for socioeconomic development in rural communities. For example, Chinsembu and co-workers applied TK to the prevention of HIV/AIDS (Human immunodeficiency virus infection/ acquired immune deficiency syndrome) in Namibia [2]. To treasure TK only through the prism of neoliberal commodification is to miss the point. It breeds spaces of existential angst, the mistaken feeling that as long as Western knowledge does not validate and accept African TK, then TK lacks meaning and value. Current ABS policy in Africa seems to embody the peripheralization of the intrinsic philosophical, spiritual, and cultural values of African TK. It goes without saying that scientific validation of TK of medicinal plants demeans the accuracy and empiricism of TK, which has been passed on for millennia from generation to generation. A critical rethink of ABS policy and decolonization of African education systems should make it blatantly clear that there are values of African TK beyond its current commodification as is being lauded by the neoliberal pundits of monopoly capital. To dispel such erroneous notions, Nkondo [100] contended that TK should not be equated to primitive anthropology because, in any case, TK, much like Western knowledge, already fits into the two epistemological denominations of rationalism and empiricism. It seems there is a conflict between various uses of TK: For TK holders and the society as such, TK will always have priceless, symbolic, and cultural values; for commercial users, this TK has to be proved during the product development process otherwise the product cannot reach the market.

\subsection{Defensive Versus Positive Protection of TK}

Defensive protection aims to prevent people outside the community from acquiring IPRs over TK and ethno-genetic resources [101,102]. Defensive tools focus on the patent system [103] and supportive databases [104] to which examiners can refer when assessing prior art. This is an obligation related to the CBD's Article 7. Unfortunately, Namibia has no known databases of TK, and because patenting of TK is difficult, acquiring prosecutorial muscles to mount successive defensive protection of TK resources shall prove to be arduous if not feeble. Further, due to strict permit requirements, the Namibian law makes it difficult to construct inventories of ethnomedicinal plants and medico-botanical knowledge. This is despite the fact the CBD argues for the conservation of bioresources through the compilation of inventories. In Namibia, Krugmann et al. [23] maintained that inventories are important because data on the misappropriation of ethno-genetic resources are scanty. Equally important is the fact that documentation and digitization of ethnobiological knowledge is one of the comparators used in examining patent and other IP petitions [105].

However, in its current format, Namibia's ABS law does not support inventorization of ethnobiological resources and associated TK. This is in sharp contrast to other countries, like Indonesia, which seek to protect their wealth of ethnomedicinal plant knowledge by tracking, preserving, promoting, documenting, and digitizing TK in a manner that is easily accessible [105]. While Namibia's Industrial Property Act accords defensive protection to TK and ethnobiological resources, Jacobs [106] argued that defensive protection was an impediment to the patenting of inventions based on or derived from ethno-genetic resources and associated TK because such patents would be invalid. According to Jacobs [106], patents of TK-based products should not fall short of the patentability requirements, as provided for under the TRIPS Agreement, because the claimed TK-based invention must be new, non-obvious, and applicable in the industry. In other words, the moral weight and ethical imperatives to protect TK-based products are overwhelming, yet copyright laws do not sufficiently protect indigenous IP [107].

Krugmann et al. [23] lamented that conventional Namibian IP law does not cover inventions and innovations of Indigenous and local peoples. The contributions of Namibian TK holders to plant breeding, genetic enhancement, biodiversity conservation, and global drug development are not recognized, compensated, or even protected. Similarly, the TK of Indigenous and local peoples is not 
treated as IP worth protecting, while the knowledge of modern scientists and companies is granted protection. It has even been argued that unless TK is so unique that it leads to ground-breaking or revolutionary innovations, such as a cure for cancer, TK holders should not obsess over protecting their IP, but rather focus on building a proof of concept that is strong, viable, and workable [108].

Instead of worrying that their TK would be stolen, TK holders should rather focus on building a powerful TK-based product or brand that customers would want to support. The difficulty in protecting orally-transmitted TK as IP has motivated calls for establishing community-level registers and biocultural protocols, which can list relevant items of TK for possible use and protection, and also to enhance community awareness of the potential value of that TK. Sadly, this aspect has been left out of the current Namibian Act. Patentability requirements are an obstacle to the protection of TK in Namibia. Sui generis laws would be more suitable in Namibia because current laws point to practical difficulties that patents of TK-based products may face given their obvious lack of novelty and non-obviousness.

Positive protection is the granting of rights that empower communities to promote their genetic resources or TK and control the uses and benefits from the commercialization of their genetic resources and TK. These regimes allow right holders to acquire existing IPRs and copyright or new sui generis rights over genetic resources or TK. Jacobs [106] asserts that Namibia's ABS law provides positive protection because it grants local communities rights to authorize or deny access to and use of their genetic resources and associated TK. It also gives them the right to benefits arising from the authorization of such access and use of their genetic resources and TK. Still, granting of IPRs over genetic resources or copyrights over TK is very cumbersome [105]; hence, to curb exploitation, defensive protection could be more workable than positive protection [109].

Besides the 2017 ABS law, Namibia's Industrial Property Act of 2012 seeks to provide positive protection for the country's ethnobiological resources and associated TK. However, there is no well-defined link between the patent law (Industrial Property Act of 2012) and the 2017 ABS law [106]. For this reason, Namibian courts may settle disputes by resorting to South African decisions on patent law. The South African Patents Act of 2012 and the National Environmental Management Biodiversity Act (NEMBA) of 2004 are helpful because the link between patent law and ABS law is clearly represented by Form P26 [106]. Whichever way one looks at it, both defensive and positive legal regimes to protect ethno-genetic resources and associated TK in Namibia are still frivolous and vexatious. By adopting the language of human rights, community rights, and biodiversity conservation, it may be possible to transcend dilemmas that continue to confront defensive and positive laws premised on contemporary IP theory and incentives, because this approach is often too mechanical, narrow, and hostile to the concerns of Namibian TK holders.

\subsection{Delimitation of Community is Ambiguous and Narrow}

The Access to Biological and Genetic Resources and Associated TK Act of 2017 defines a 'local community" as "a group (a) living or having rights or interests in a distinct geographical area within Namibia with a leadership structure and it may include natural resource management organisations, such as conservancies and community forest committees; or (b) with rights in relation to or stewardship over its natural resources, genetic resources, and associated traditional knowledge and technologies, governed partially or completely by its own customs, traditions, or laws" (p. 6). This delimitation of 'community' presents serious conceptual and practical difficulties because few communities form discrete, easily discernable groups, and most have problematic leadership structures [66].

Due to migrations, some of the tribes (San, Herero, Lozi, Aawambo) are dispersed and regionally clustered beyond Namibian national borders. However, transnational tribal communities possess the same shared TK because they are descended from the same progenitor stock. Since TK is a collective resource aggregated by a tribal community descended from the same ancestral stock, its value and resilience are created by the sum of many individual user contributions [110]. Transmitted through a common language, TK has a collective originator beyond the jurisdiction of national borders [111]. 
It is a collective understanding or repertoire of competencies created, innovated, and attained over long periods of time. By being adapted to particular ecological niches beyond national boundaries, TK represents a strategic link between an ancestral community and the Earth [111,112].

We argue that given these epistemological and genealogical pedigrees that undercut the origin and possession of ethnobiological knowledge, the Namibian Act's national delimitation of community, rather than a transnational delineation, is parochial as it does not recognize that a tribal community is amorphous and may be spread across neighbouring countries yet still share ethnobiological knowledge from the same primordial stock. The biocultural heritage and diversity of TK bear the footprints of tribes that migrated beyond the realm of today's national borders. Again, the Act's geopolitical demarcation of community is therefore narrow in scope because it fails to recognize that TK holders are a community of practice and knowledge workers can easily reside in countries beyond the borders of Namibia [113].

In any case, because ethno-communities are also in a state of flux given the nature of global migration, States are encouraged to uphold the human, social, and economic rights of migrants [114]. Eco-justice and the IPRs of TK holders are human rights issues beyond the jurisdiction of States $[115,116]$. Accordingly, community TK is recognized in international law [117]. Taken together, we contend that the proviso relating to the homogenous and national definition of community is ambiguous and frivolous because TK holders may live beyond Namibian borders, making it difficult to come under the aegis of this nationalistic ABS regime. It is regrettable that the definition of 'community' in this Namibian Act did not benefit from the trans-boundary and regional ABS case involving Hoodia and the San people. Lewis [118] also observed that one issue that is covered by the NP, but not by South Africa's ABS law, is cooperation with neighbouring countries concerning trans-boundary species or TK.

With the benefit of hindsight, any fair and reasonable TK-based ABS agreement that recognizes the rights of the San people in Namibia will also have to provide for the rights of the San who now live in Angola, Botswana, South Africa, Zambia, and Zimbabwe. The same holds for any ABS agreement involving the TK of the Herero people; it ought to distribute benefits to the Herero people in Namibia and Botswana. It is also logical that any ABS arrangement involving the TK of the Lozi people must also recognize the rights of the Lozi people who live in Namibia and Zambia. Likewise, it behooves any TK-based ABS agreement to extend benefits to all the Aawambo speaking people who live in Namibia and Angola, and the Tswana people found in Namibia and Botswana, respectively. Needless to state that a precedent was set by the Hoodia ABS agreement between CSIR and the San people whereby the rights of and benefits to the San TK holders were not restricted to the South African San alone. Benefits were naturally extended to the San people in Botswana and Namibia, but the South African San - perhaps due to strong political representation - received a lion's share. The San of Angola, Zambia, and Zimbabwe were excluded from the Hoodia ABS agreement because the plant is endemic to the Kalahari Desert of Botswana, Namibia, and South Africa.

Krugmann et al. [23] argues that there are no universally accepted and unequivocal definitions of terms, like "community" and "customary rights". Corollary, their meanings within the Namibian context should be clarified on a case-by-case basis. There were also concerns that a 'community' sometimes consists of two powerful families that wrangle over the sharing of communal benefits to the exclusion of other community members [97]. Similarly, the Herero and the Kavango people rarely extend benefits to the San communities, which are often exploited for cheap labour. That being said, the case of Argemone mexicana, a plant used to make an improved antimalarial herbal drug in Mali, illustrates that respect for the community's IPRs and the fair sharing of benefits may be possible even where TK is not owned by a clearly defined person or community [67].

\subsection{The Need for Confidentiality}

Trade secrets and confidential information are invaluable in protecting a wide range of Indigenous IP in Australia [119]. According to the World Intellectual Property Organization (WIPO), 
any confidential business information that provides an enterprise a competitive edge may be considered a trade secret [120]. The protection of trade secrets or confidential information is one of the ways to safeguard against unfair competition. To qualify as a trade secret, the information must be commercially valuable, be known only to a limited group of persons, and be subject to reasonable steps taken by the rightful holder of the information to keep it secret using confidentiality agreements. Trade secrets are IP rights on confidential knowledge that can be sold or licensed.

The unauthorized acquisition, use, or disclosure of such secret information (e.g., antimicrobial efficacy data for medicinal plants) in a manner contrary to honest commercial practices by others is regarded as an unfair practice and a violation of trade secret protection. Although a trade secret approach to protecting TK is important [14], the 2017 Namibian ABS law does not have a provision for safeguarding confidential information (trade secrets) that may be important during commercialisation. In fact, the word, 'confidential', is not mentioned anywhere in the 2017 Namibian Act. This means that even after entering into ABS agreements, community TK right holders may disclose trade secrets to third parties. This is more so because local communities in Namibia usually find it difficult to handle sensitive commercial information in a confidential and transparent manner [23].

Not that the law in South Africa is earth-shattering, but undeniably, ABS law in Namibia should show the same sense of purpose and intellectual lucidity, like South Africa's NEMBA, which has paid particular heed to protect trade secrets or confidential information, including details of species to be collected and areas in which species are collected [106]. Under NEMBA, confidential material includes financial, commercial, scientific, or technical information, including trade secrets and Indigenous knowledge, which, if disclosed, may be detrimental to the commercial or financial interests of a party to an ABS agreement. However, confidential information excludes data published in scientific journals and information that parties consent to disclose. The 2003 Hoodia ABS agreement did not permit San TK holders to disclose information about the medicinal properties of the plant to third parties.

TK of biological resources may include sensitive and confidential information, such as the repertoire of ethnomedicinal plant species, which could form trade secrets for which competitors may access vital IP. Thus, confidentiality and security policies could help increase competitiveness. Bertino et al. [121] recommended that various access-control techniques, including role and read-write policies, can be applied to the management of ethnomedicinal plant knowledge to ensure confidentiality. Secure TK management strategies should be tightly integrated into the research and commercial bioprospecting strategy. Over and above the need for confidentiality, ABS agreements should be built on trust, the firm belief in the competence of parties to the ABS to act dependably, securely, and reliably [121]. Trust is incrementally built by iteratively disclosing credentials to verify properties of parties to the negotiation. Thus, a key component of trust negotiations is disclosure policies governing access to ethnobiological resources and TK. Trust management and negotiation are a prelude to confidentiality and TK management.

Although it is difficult to legislate trust, lack of trust may lead to the leakage of sensitive confidential information (including ethnomedicinal plant species and active principles) to third parties. ABS agreements should therefore include trust negotiations between community right holders (entities owning ethnomedicinal plants and TK) and users seeking ethnomedicinal plant species and TK (bioprospectors and researchers). Notwithstanding, questions still remain as to how protection measures should be enforced to secure a collective resource, such as TK, whether researchers can publish their work, if study results can be disseminated at conferences, and whether patents must include TK holders. To what extent confidentiality clauses could preclude customary transmission of tacit TK is also not clear. What is clear though is that following the example of South Africa, the national IKS policy plans to develop a recordal system of TK in Namibia. We therefore concur with Rimmer [119] that careful consideration should be given to the interaction between a national database for the recordal of traditional IP and the protection of confidential ethnomedicinal information held by local communities. 


\subsection{ABS Law May Stunt Research in Namibian Universities}

According to the University of Namibia (UNAM) Act 18 of 1992, the academic goal of UNAM is to provide higher education, to undertake research, to advance and disseminate knowledge, to provide extension services, to encourage the growth and nurturing of cultural expression within the context of the Namibian society, to further training and continuing education, to contribute to the social and economic development of Namibia, and to foster relationships with any person or institution, both nationally and internationally [122]. The Act also defines academic staff as all those persons employed by the university whose conditions of employment include the obligation to undertake teaching and research.

The Namibia University of Science and Technology (NUST) Act 7 of 2015 also states that NUST shall contribute to knowledge creation and advance knowledge through teaching, research, and scientific investigation, with an emphasis on applied research [123]. In addition, NUST shall preserve and promote the traditional and constitutional principles of institutional autonomy and academic freedom in the conduct of its internal and external affairs. NUST academic staff members are required to undertake teaching and research. Shaped by Namibia's Vision 2030, the conventional mission of Namibian universities is predicated on its ability to autonomously conduct research and help power the country's industrialization. Unfortunately, most of the two universities' research, which is dependent on prompt and unfettered access to ethnobiological resources, will now be stymied by this ABS law. As Namibian universities struggle to cope with the 'scissors effect' evidenced by cutbacks in government subventions, this ABS law may now be the straw that broke the camel's back.

To foster the ideals of a knowledge economy, governments all over the world are withdrawing from their previous positions of total control of science and technology policy, adopting instead more laissez faire principles [124]. This is not the case in Namibia where the current ABS law imposes strict controls on research and sharply undermines the goals, mission, and autonomous work of universities [125]. By overly restricting access to ethnobiological and genetic resources and associated TK, Namibia's ABS law complicates the role of universities in conducting research on ethnobiological resources and TK. It stunts universities' essential contribution to the Indigenous knowledge economy. The new law also imperils human capital development in fields, such as ethnobiology, ethnomedicines, pharmacognosy, and taxonomy.

Martinez and Biber-Klemm [126] asserted that the ABS system under the CBD was originally conceived for commercial research or bioprospecting, the search for useful organic compounds that can be isolated from nature, and if possible, synthesized, patented, and developed into commercially successful products. They argued that the spirit of ABS legislation was not meant to regulate academic research not meant for commercialization of results or the development of marketable products. Biodiversity research generates critically important knowledge for the implementation of the CBD, yet academic and non-commercial scientists intending to study biodiversity experience obstacles caused by restrictive access laws [126]. Since access procedures are geared toward industrial product development and are often oiled by unrealistic upfront payments, the current ABS law in Namibia, as in many provider countries, is not responsive to the specific needs of academic non-commercial research.

In fact, the current Namibian ABS law seems to be a capitulation on Shikongo's earlier undertaking that ABS legislation would only target TK used to shortlist bioprospecting targets [39]. Through its overt emphasis on monetary benefits, the current Namibian ABS law makes it difficult for low-budget researchers to undertake negotiations with communities, as the 'right holders' will now explicitly demand up-front payments, including the sharing of research funds. Since most right holders are illiterate, receipting for ethnobiological resources and associated TK will become problematic; this will create challenges in the accountability and audit of research funds. Unlike the South African ABS law, which provides for collection and research permits to be issued by provincial authorities, the Namibian law places too much emphasis on centralized regulation through government control of academic research permits instead of devolving powers, permit procedures, and benefit-sharing to local authorities and ethical clearance committees in universities. 
There are four necessary steps required to ethically and successfully conclude a consent process, namely, legitimization to consent, full disclosure, adequate comprehension, and voluntary agreement [127]. Such inflexible steps and bureaucratic lags in ABS negotiations will generate excessive delays, which will, in turn, jeopardize university research productivity. Tedious access procedures with numerous levels of bureaucracy will slacken decision-making processes, amplify university research costs, and blur accountability and transparency. These practices will put a brake on non-commercial research outputs in the universities. Unlike industrial bioprospecting, academic research does not have the financial or organizational flexibility for long-lasting negotiations as postgraduate and donor-funded research projects need to fulfill set goals within a short period of two to three years. Currently, approval for collection permits takes more than one year [125]. Under this new ABS law, the waiting time to get a research permit will now be much longer because researchers will first be required to get PIC in addition to signing a BSA. Stringent ABS conditions will, from now onwards, increasingly deter scientists from conducting research in the fields of ethnobiology and ethnomedicines. Over time, the consequences for universities as hotbeds of research and innovation will be too ghastly to contemplate.

There is an urgent need to streamline procedures for access permits to ethnobiological and genetic resources, especially for research students and research with no commercial intents. Since onerous access regulations bring forth new challenges for academic research, ABS laws should be amended so as to simplify procedures, adapt to research needs and best codes of practice, and involve scientists in national ABS permit granting committees [126]. To achieve this, universities in Namibia at the highest tiers of research management must take a stand based on critical discussions and an informed understanding of the intricacies of this new ABS law in as far as it impinges on their traditional autonomous role to undertake research and innovation, especially in the fields of ethnobiology and ethnomedicines [125]. All over the world, scientists are concerned about exceedingly obstructive and bureaucratic permit requirements for ethnobiological and ethnomedicinal research [128-130]. In India, ABS requirements have driven away international collaborators and funding in fields, such as taxonomy, where the country has limited expertise [131]. In light of this new Namibian ABS law, what happened in India may happen in Namibia. Apart from the imprisonment of scientists, outrage against ABS laws revolves around the lack of clarity regarding derivatives of ethno-genetic material, legislation of genetic resources that were obtained before passing ABS laws, and whether the CBD should follow international ABS standards or allow a case-by-case determination [132].

According to Crouch et al. [133], it is not correct to imagine that ethno-genetic resources and ethnomedicinal plants are always commercializable entities awaiting 'cherry picking' by bioprospectors and the industry. In practice, only a small fraction of scientific research based on local plants and associated TK yields commercial or industrial products. Only 1 in 250,000 ethnomedicinal plant samples directly lead to a commercial drug [26]; this scenario may have improved given the recent pace of technological innovation. Further, the discovery phase of bioprospecting, which yields mostly academic taxonomic information, is irrelevant to poor communities desirous of hard cash benefits [133]. The frivolity of ABS legislation has also become eminent in the wake of the current bioprospecting bust $[13,133,134]$. Over the past 30 years, bioprospecting has failed to deliver on its primary promise of finding a blockbuster drug [13]. Consequently, many multinational pharmaceutical companies have shut down their natural products divisions in preference for new, less expensive, and more scientific methods to drug discovery, including the generation of computer-generated molecules [134].

Like other exceedingly restrictive ABS laws, Namibia's 2017 ABS Act is ostensibly flawed because it myopically focusses on the point of collection and fixates on the specifics of permits (access, bioprospecting, export) and compensatory agreements (ABS, MTA) while losing sight of the much larger and far more significant questions surrounding the ownership, potential value, and future usage or innovation of the ethnobiological collections [135]. ABS law should encourage product development from ethnobiological resources and related TK to maximize local value addition and build national R\&D capacity. Regulation of research-related access to ethno-genetic resources must 
carefully balance the need for control to ensure benefit-sharing and prevent biopiracy, on the one hand, and the importance of encouraging legitimate research activities, on the other. Regulating access to ethno-genetic resources should not put a brake on legitimate research activities, value-addition, and R\&D capacity in Namibia.

\subsection{Botanic Gardens}

Hulme [136] defines a botanic garden as an institution holding documented collections of living plants for the purposes of scientific research, conservation, display, and education. Often linked to universities or scientific research organizations, botanic gardens and associated herbaria provide numerous benefits, including conservation, education, recreation, and tourism [94,137]. As educational institutions, botanic gardens mainly showcase plant diversity and conservation [138], and uniquely teach about environmental issues or raise public awareness about biodiversity loss [139]. The National Botanic Garden of Namibia (NBGN), a section of the NBRI, cultivates and conserves Namibian Indigenous plants, conducts taxonomic research, propagates Indigenous ornamental plants, and rescues sensitive and protected plant species that face loss of natural habitats due to anthropogenic activities [94]. NBGN is a nature reserve, which has adopted the ex situ conservation approach whereby Indigenous plant species are protected as living and seed collections [94,140]. Namibia's current ABS law defines ex situ conservation as a condition wherein biological and genetic resources are housed, planted, stored, kept, or found outside their natural ecosystem or habitats, such as herbaria, research institutions, universities, botanical gardens, private collections, and any other similar conservation centres [21].

By bringing NBGN's works under the aegis of the new ABS law, NBGN's traditional roles and efforts in ex situ conservation, education, research, and international scientific collaboration, especially taxonomic identification and cross-referencing of species, may be negatively affected and slowed down. Strict access permits, as promulgated by the new ABS law, will translate into inadequate accession data; this will, in turn, compromise the conservation value of plant collections [141]. Since its inception, NBGN has been strengthening international linkages and establishing new collaborations with global research partners [85]. However, because this new ABS law feeds the growing trend of populist economic nationalism, it may hamstring NBGN scientists by putting them at the risk of not collaborating in international research projects. Regrettably, the role of NBGN to conduct extensive surveys to document ethnomedicinal plant use in the field with the help of international collaborators [85] will be scuppered by this restrictive ABS law. This ABS law may prevent NBGN, which has conventionally been a leader in setting the standards necessary for sharing the benefits of materials found in their germplasm collections [142]. Other than usurping the traditional role of botanic gardens, this ABS law may also aggravate niche tensions between government functionaries in NBGN and the Act's proposed top-heavy ABS permitting authority, the Directorate of Biological and Genetic Resources and Associated Traditional Knowledge.

\subsection{South African Law Differentiates between Commercial and Non-Commercial Research}

Crouch et al. [133] bemoaned that, historically, a lack of bioprospecting legislation and associated regulations has permitted unconstrained access to South African bioresources, with materials being harvested, sometimes in destructively excessive quantities, and exported to R\&D institutions abroad for innovative value addition and off-shore financial benefit. The consequence has been that TK holders and bioresource providers have not benefited equitably from the monetary gains derived from the commercialization of their bioresources. The European Patents Office granted patents to Schwabe Pharmaceuticals, a German pharmaceutical company, for certain treatments containing South African Pelargonium species. These patents were related to methods of obtaining extracts, see: https:/ / patents.google.com/patent/EP1429795B1/en. This was despite the fact that Schwabe neither obtained PIC for the use of the plants nor signed any BSA regarding the use of the plants and associated TK [118]. 
When seen against this backdrop, the 2004 NEMBA and 2008 Bioprospecting, Access, and Benefit-Sharing (BABS) Regulations were enacted to provide for a permit-issuing system for South Africa's Indigenous biological and genetic resources and associated TK $[106,133]$. NEMBA and BABS incorporate both PIC and benefit-sharing requirements. Chapter 6 of the 2004 Act specifically focuses on ABS [133]. Although the Biodiversity Act only articulates a broad framework for ABS, opting to leave details to subordinate regulations, the three objectives of the 2004 Act mirror those of the CBD, namely: To provide for the management and conservation of biodiversity, the sustainable use of Indigenous biological resources, and the fair and equitable sharing among stakeholders of benefits arising from bioprospecting involving Indigenous biological resources [143]. Besides NEMBA and BABS, the Patents Amendment Act of 2005 requires an applicant for a patent to furnish information relating to any Indigenous biological resource or TK that could be part of the submitted invention and, if so, provide proof that applicant(s) have received permission to make use of the Indigenous resource or TK [133].

Unlike the CBD and NP (and by extension Namibia's 2017 ABS Act), South Africa's ABS laws do not refer to the 'utilization' of genetic resources, but rather to 'bioprospecting' involving Indigenous biological resources [118]. This is apt because terms, such as 'utilization', do not necessarily have a definition understood by courts of law; the term, 'utilization', is difficult to enforce in ABS contracts [142]. As defined by the NP, 'utilization' of genetic resources means to conduct research and development on the genetic and/or biochemical composition of genetic resources, including through the application of biotechnology. 'Bioprospecting', on the other hand, is defined by South African law to mean research on, or development or application of, Indigenous biological resources for commercial or industrial exploitation [118]. The National Environment Laws Amendment Bill, published in the Government Gazette No. 31075 of 20 May 2008, stipulates that anyone engaging in the discovery phase of bioprospecting must notify the minister and sign a commitment to comply with the legal requirements when the commercialization phase of bioprospecting is reached [133]. Thus, a bioprospecting permit and the concomitant need to negotiate BSAs are only required at the start of the commercialization phase of bioprospecting $[133,143]$.

Stated differently, in contrast to Namibia's 2017 one-phase ABS law, which lumps commercial and non-commercial research, South Africa's NEMBA is two-phased, hence more progressive as it draws a distinction between research that has a commercial purpose and non-commercial research for academic purposes. NEMBA distinguishes between the discovery and commercialisation phases of bioprospecting, with bioprospecting permits only being required for those activities that fall into the commercialisation phase [118]. Research other than bioprospecting that is conducted entirely within South Africa is completely exempt from NEMBA's bioprospecting provisions. Simplified measures on access for non-commercial research purposes as anticipated by the NP are present in South Africa's ABS regime, but conspicuously absent from Namibia's 2017 ABS law. Still, one issue that is covered by the NP, but not by South Africa's ABS laws, is cooperation with neighbouring countries in respect to trans-boundary species and TK [118]. This shortcoming was a problem for CSIR scientists during efficacy and toxicity testing of the anti-HIV Sondashi Formula (SF-2000), which required trans-boundary movement of SF-2000's four constituent plants from Zambia [10].

That the South African government, despite NEMBA and BABS, has ties of amity and commerce with researchers working on the intersections of TK and medicinal plants is exemplified in the Department of Science and Technology's financial support to the Novel Drug Development Platform (NDDP). The NDDP is a broad-based consortium of local researchers from clinical and scientific disciplines based in local parastatals, universities, and science councils. The objective of NDDP is to develop novel malarial, tuberculosis, and diabetes mellitus drugs from ethnomedicinal plants [133]. Government funding to NDDP is in line with the government's policy that it is in South Africa's best interest to ensure that access to biodiversity is not utterly restrictive; hence, ABS legislation should spur economic activity [133]. Government policy has recognized that South Africa's emerging economy can ill-afford to restrain its own bioprospecting activities through unreasonable and cost-prohibitive 
regulations [133]. Unlike the South African ABS regulations, the Namibian ABS law in its current form is not erected on a clear conceptual understanding of the economics of the research and innovation value chain, which evolves from basic and non-commercial research (discovery stage) to R\&D and commercialization. BSA regimes should not be cast in stone; they ought to be flexible, to make allowance for changes in benefit-sharing arrangements as research results leapfrog and concretize towards sellable products.

Research done in South Africa that is not needed for commercialisation does not require a bioprospecting permit; only a collection/research permit is obtained from the provincial authority. South Africa allows discovery of value, but regulates R\&D for commercial and industrial exploitation. Namibia has a one-phase PIC system, which restricts the discovery of value. South Africa has a two-phase PIC system, which distinguishes research during the discovery phase and research during the commercialisation phase. In South Africa, there is a collective understanding that there are no benefits at the early stages of exploratory and survey researches because benefits take long to derive, and are usually attained after a critical stage of painstaking discovery research. Since Namibian ABS law does not recognise this principle, it may even discourage discovery research leading to innovation of Indigenous processes and products. Crouch et al. [133] pointed out several lessons to learn from South Africa. According to these authors, when regulations relating to access to bioresources are biased against commercial research, they typically tend to impact negatively on basic research. Widespread suspicion that bioprospecting could take place under the guise of basic research stimulates over-regulation, well exampled by legislation drawn up by several developing nations, including Sri Lanka, Brazil, and the Philippines. It is therefore important to designate clear limits between access to material for bioprospecting purposes and access for any other kind of research.

Understandably, research at the lower end of the pipeline rarely produces any economic benefits. Plus, there is a time lag between discovery research and convention of research outputs into commercial products and economic gain. In future, it would be prudent to amend Namibia's 2017 ABS law so that it discerns between commercial and non-commercial research. Such an amendment will shore up the key goal of Namibia's National Programme on Research, Science, Technology, and Innovation (NPRSTI), namely to [144]: "Ensure that Indigenous knowledge is properly documented" (p. 14).

In the meantime, Namibian researchers working on the intersections of IKS and drug discovery have been thrown a legal curve ball. Enactment of the Namibian ABS law in 2017 also represents a very low point in the year when there is a moratorium of NCRST funding for research. Many Namibian researchers will be disinclined to screen ethnomedicinal plants given the uncertainty and cost-inefficiency brought about by the current restrictive ABS law [133]. Yet, as the Namibian government amps up pressure on biopiracy, this ABS law is the shot at the silver lining. It is a visual aid of the government's calculus for economic justice and beneficiation from the country's largely underworld green economy.

\section{Other Contrasts between Namibian and South African ABS Laws}

On many fronts, several provisions do stand out. In terms of purpose, Namibia places emphasis on restricting access to ethnomedicinal plants, but South Africa aims to regulate bioprospecting. Namibia's restrictions on access to bio-genetic resources and TK may hinder research and innovation; they point to judicial overreach as the ABS law usurps many responsibilities which fall under the ambit of other institutions, such as universities and botanic gardens. In Namibia, institutional administration of the Act (part 3) provides for the establishment of a Directorate of Biological and Genetic Resources and Associated TK; this Directorate will establish the R\&D facility on Indigenous biological natural resources. In South Africa, institutional administration of the Act only deals with regulation (part 1), and consultation or public participation (part 2). Unlike the Namibian ABS law, counterpart legislation in South Africa does not have overreach into $R \& D$, a role which is left to universities and the industry, because government focuses on enacting regulations relating to monitoring and compliance with approved norms and standards. Namibia's Directorate of Biological and Genetic Resources and 
Associated TK, instead of focusing on regulation and cooperative governance, ventures into R\&D. Yet, this proposed Directorate, in relation to experienced universities and research institutions, has no comparative competencies and infrastructure to conduct R\&D.

The Namibian Act explicitly stipulates in 10(2)(viii) that research funding is a monetary benefit. Clearly, this is vexatious as it may lead to conflict and distrust for the simple reason that right holders expect to receive money emanating from research grants obtained from donors and funding agencies. The South African law is silent on research funds being cited as benefits to the community. In Namibia, monetary benefits are paid into the Environmental Investment Fund (EIF). This money shall be used to foster scientific research, provide training and education, and raise awareness. In South Africa, money is paid into the Bioprospecting Trust Fund (BTF) and the Community Trust Fund distributes benefits to the community. The EIF is much broader and less accountable than BTF; hence, money paid into the BTF is more likely to benefit stakeholders involved in bioprospecting than money paid into the EIF. Money paid into the EIF may easily be used to pay for any other expenses related to the administrative functions of the Directorate of Biological and Genetic Resources and Associated TK. This may open a window for the abuse of funds by officials in the Directorate.

The law in South Africa gives up to four months as the waiting period before a permit is issued (counting only working days, Monday to Friday, excluding public holidays and weekends). Namibia does not stipulate the waiting period, meaning that issuance of a permit could even take a year or longer. In Namibia, the law is also not clear on the regulation of ethnomedicinal plants located on private farms. Unless the ethnobiological resources are on State land, the law does not vest ownership in the State, meaning the landowner in South Africa owns ethnobiological resources on their property. However, the State is a trustee of biological diversity in South Africa. The Namibian law provides for penalties not exceeding $\mathrm{N} \$ 150,000$ or jail time not exceeding ten years, or both. Up to 10 million South African rands, or three-times the commercial value of the activity or jail time of up to 10 years is stipulated in South African ABS law.

\section{Conclusions and Recommendations}

Over the past few years, there has been a tectonic shift in the global acceptance of ABS laws. Therefore, this paper traces Namibia's development of ABS legislation, the Access to Biological and Genetic Resources and Associated TK Act of 2017, from two vantage points: International frameworks, including the CBD, NP, African Model Law, Bonn Guidelines, and the Swakopmund Protocol; and the country's administrative, institutional, and bio-economic contexts. Unless the historical roots, socioeconomic subtexts, and administrative agencies of the ABS law are clearly distilled, fidelity to its enforcement shall remain elusive. By putting the international and domestic contextual impetus behind this ABS law into perspective, stakeholders can summon the requisite urgency to implement the law with missionary zeal.

Although the green economy may represent a prospective source of income to reduce poverty, monetary benefits disproportionately accrue to middlemen and exporters, instead of local harvesters. Thus, current biotrade practices offer poor socioeconomic contracts to local communities. Systemically embedded in the country's post-Apartheid past, Namibia's green economy, it has been argued, is eudaimonically questionable primarily because it lacks corporate responsibility, suffocates the wellbeing of the local people, and short-changes them of monetary benefits. The Access to Biological and Genetic Resources and Associated TK Act of 2017 is a fitting rejoinder to unfair biotrade practices in Namibia. In theory, the new ABS law brings timely hope to restructure the country's unequal and neo-Hobbesian expropriation of ethnobiological resources and profiteering from biotrade. It is a visual aid of the government's efforts to restore parity in the country's green economy, a stinging rebuke of systemic inequalities mainly inherent in the phyto-trade sector.

Given that local communities lack the economic wherewithal and technical skills capacity to negotiate on an equal footing with biotrade agents and export markets, the current ABS law opens a significant channel for equitable monetary and in-kind benefits to local communities. In line with the 
Harambee Prosperity Plan, this law is an important lynchpin in the fair redistribution of economic benefits. Agreed, the ABS law is a shot at the silver lining, but it is not a fait accompli because no carefully designed legislative machinery can practically take the place of good corporate responsibility and ethical behaviour in biotrade and bioprospecting. Still, the current ABS law may be emboldened into life by the urgency of those in authority and the action of citizens. This may help unlock the wells of economic and social justice in a nation that loathes the haemorrhage of profits from the bio-economy.

The current ABS law is not without schisms, risks, and questions on several fronts. There is criticism that the authorities may have ramrodded through the new ABS legislation while blindsiding critical stakeholder scrutiny and input, especially from universities. In its delirium to correct imbalances in the distribution of benefits from biotrade, the law has unfortunately put bioprospecting, an enterprise still in its infancy in Namibia, onto a slippery slope. In many ways, Namibia's ABS architecture in its present form is a poisoned chalice [125]. While the law is well intentioned to regulate biotrade, it is, in stark contrast, overly restrictive for non-commercial research in universities and botanical gardens. Seen as an obstacle to the discovery phase of bioprospecting, this ABS law may therefore be mischaracterized as a blinding impediment to innovation, value-addition, and drug discovery. The law's commodification of genetic resources and TK also subtracts from the inherent cultural and non-physical values of TK.

With respect to commercial and non-commercial bioprospecting, government should formulate practical guidelines to help enforce the new ABS law. The proposed structures that ought to operationalize critical provisions of the Act should be formed and strengthened. Without functional structures, implementation of the Act will remain in a technical grey area, making ABS a figment of our imaginations. This will complicate an already dire situation whereby collection permits for academic research on ethnobiological resources are being issued after waiting for more than a year. Publication of research data from ethnobotanical studies and medicinal plants is also on hold. In its current form, the ABS law has seismic impacts on research. Not only has this law put a brake on scientific productivity, but government has almost immediately and squarely put university researchers into its legislative crosshairs. The motive and urgency for beneficiation should not circumvent access to ethnomedicinal plants and associated TK for the purposes of non-commercial scientific research, innovation, and value addition.

Even if several canons of the CBD and the NP are acknowledged in the Namibian law, their feasible applications in the restoration of economic parity remain unknown and a far-fetched bio-economic dream. The case of Hoodia and the San not only illustrates several major challenges of ABS legislation, but also speaks to the urgency for regional and national ABS regimes to bring economic benefits to impoverished communities, which collectively own critical TK used in commercial bioprospecting. We recommend that either the law should be amended or suitable guidelines should be erected to provide for a balanced yet nuanced suite of workable sticks and carrots. This will require a herculean shift in the fundamental understanding of the ABS mantra, in particular among leading voices in government-quasi government institutions and gatekeepers in local communities.

Two assertions can be made about this law. First, in the face of high poverty levels in Namibia's countryside, this ABS law may as well represent fresh crocodile tears for the rural have-nots. This assertion is backed by palpable lacunas between statute formulation (legal substance) and policy implementation (law enforcement) in Namibia. Second, and more importantly perhaps, is the fact that this law is still a lost ball in the high weeds. This is illustrated by the fact that, although the law was developed by considering the lived experiences of the nation and local communities, operationalization of the Act at a granular level through supportive guidelines and structures has not yet been done. South Africa's ABS legislation and guidelines are comparatively more progressive than Namibia's current law on Access to Biological and Genetic Resources and Associated TK. Since the law is dynamic, we recommend that Namibia should amend the 2017 ABS Act to suit current conditions, specifically to differentiate between non-commercial (discovery phase) research from commercial bioprospecting (high-end product development research). As in South Africa, Namibian law should provide for a less 
restrictive, but more practical, approach to negotiate BSAs after the commercial or industrial value of a bioresource has been determined.

We recommend that Namibian law should be amended to bring on board a more lucid definition of community, to provide for confidentiality of sensitive trade secret data, and allow universities to access ethnomedicinal plants and TK resources in line with their autonomous teaching and research portfolios. The current law should be clear on ABS agreements in the blue economy if the country is to fairly benefit from biological resources in the ocean and rivers. ABS negotiations require trust, and the success of any ABS regimen is a constant work in progress. When seen in this light, enforcement of Namibia's Access to Biological and Genetic Resources and Associated TK Act of 2017 is a daunting reality as much as it is a beautiful prospect. A sea-change in stakeholders' attitudes and government machinery is urgently needed if Namibia's ABS law is to be successful.

Author Contributions: W.W.C. provided formal legal analysis and contributed to writing of the original manuscript. K.C.C. conceptualized the study and contributed to writing of the original manuscript.

Funding: This research received no external funding.

Acknowledgments: Charles Luchen is thanked for drawing Figure 1. We thank the guest editor and anonymous expert reviewers for their useful comments on the original manuscript.

Conflicts of Interest: The authors declare no conflicts of interest.

\section{References}

1. World Bank. World Development Report 1998/1999; World Bank: Washington, DC, USA, 1998; Available online: https: / openknowledge.worldbank.org/handle/10986/5981 (accessed on 11 November 2017).

2. Chinsembu, K.C.; Shimwooshili-Shaimemanya, C.N.; Kasanda, C.D.; Zealand, D. Indigenous knowledge of HIV / AIDS among High School students in Namibia. J. Ethnobiol. Ethnomed. 2011, 7, 17. [CrossRef] [PubMed]

3. Shen, B. A new golden age of natural products drug discovery. Cell 2015, 163, 1297-1300. [CrossRef] [PubMed]

4. Newman, D.J.; Cragg, J.M. Natural products as sources of new drugs from 1981 to 2014. J. Nat. Prod. 2016, 79, 629-661. [CrossRef] [PubMed]

5. Dybas, C.L. Wild medicine: The search for cures from nature. BioScience 2016, 66, 341-349. [CrossRef]

6. Banfi, F.F.; de Sena Guedes, K.; Andrighetti, C.R.; Aguiar, A.C.; Debiasi, B.W.; da Costa Noronha, J.; Rodrigues Dde, J.; Júnior, G.M.; Sanchez, B.A. Antiplasmodial and cytotoxic activities of toad venoms from Southern Amazon, Brazil. Korean J. Parasitol. 2016, 54, 415-421. [CrossRef] [PubMed]

7. Dutfield, G. Traditional Knowledge, Intellectual Property and Pharmaceutical Innovation: What's Left to Discuss? Sage Handbook of Intellectual Property; Sage: London, UK, 2015; pp. 649-664.

8. Holland, B.K. Prospecting for drugs in ancient texts. Nature 1994, 369, 702. [CrossRef] [PubMed]

9. Helmstädter, A. The botanical explorer's legacy: A promising bioprospecting tool. Drug Discov. Today 2017, 22, 757-760. [CrossRef]

10. Chinsembu, K.C. Model and experiences of initiating collaboration with traditional healers in validation of ethnomedicines for HIV/AIDS treatment in Namibia. J. Ethnobiol. Ethnomed. 2009, 5, 30. [CrossRef]

11. Cunningham, A.B. People's science: Southern African ethnobotany in global perspective. S. Afr. J. Bot. 2008, 74, 357. [CrossRef]

12. Jones, A.W. Early drug discovery and the rise of pharmaceutical chemistry. Drug Test. Anal. 2011, 3, 337-344. [CrossRef]

13. Neimark, B.D.; Wilson, B. Re-mining the collections: From bioprospecting to biodiversity offsetting in Madagascar. Geoforum 2015, 66, 1-10. [CrossRef]

14. Varadarajan, D. A trade secret approach to protecting traditional knowledge. Yale J. Int. Law 2011, 36, 371.

15. Parry, B. Trading the Genome: Investigating the Commodification of Bio-Information; Columbia University Press: New York, NY, USA, 2004.

16. Ten Kate, K.; Laird, S.A. Bioprospecting Agreements and Benefit Sharing with Local Communities. Poor People's Knowledge: Promoting Intellectual Property in Developing Countries; World Bank: Washington, DC, USA, 2004; pp. 133-158. 
17. Wynberg, R.; Laird, S. Bioprospecting: Tracking the policy debate. Environ. Sci. Policy Sustain. Dev. 2007, 49, 20-32. [CrossRef]

18. Brockington, D.; Duffy, R. Capitalism and conservation: The production and reproduction of biodiversity conservation. Antipode 2010, 42, 469-484. [CrossRef]

19. Reihling, H.C.W. Bioprospecting the African renaissance: The new value of muthi in South Africa. J. Ethnobiol. Ethnomed. 2008, 4, 9. [CrossRef] [PubMed]

20. Sullivan, S. Banking nature? The spectacular financialisation of environmental conservation. Antipode 2013, 45, 198-217. [CrossRef]

21. Government of the Republic of Namibia. Access to Biological and Genetic Resources and Associated Traditional Knowledge; Republic of Namibia National Assembly: Windhoek, Namibia, 2017. Available online: www. parliament.na/index.php?option=com_phocadownload\&view=category (accessed on 25 August 2017).

22. Nanyeni, F. President Hage geingob's rhetoric on "Harambee Prosperity Plan" and the shaping of Namibia's future. Afr. Yearb. Rhetor. 2016, 7, 45-55.

23. Krugmann, H.; Cole, D.; Du Plessis, P. Access and Benefit-Sharing Mechanisms for the Use of Botanical Resources in Namibia (No. 66); Directorate of Environmental Affairs, Ministry of Environment and Tourism: Windhoek, Namibia, 2003.

24. Efferth, T.; Banerjee, M.; Paul, N.W.; Abdelfatah, S.; Arend, J.; Elhassan, G.; Hamdoun, S.; Hamm, R.; Hong, C.; Kadioglu, O.; et al. Biopiracy of natural products and good bioprospecting practice. Phytomedicine 2016, 23, 166-173. [CrossRef]

25. Sanchez, V.; Juma, C. Biodiplomacy: Genetic Resources and International Relations; African Centre for Technology Studies: Nairobi, Kenya, 1994.

26. Macilwain, C. When rhetoric hits reality in debate on bioprospecting. Nature 1998, 392, 535-537. [CrossRef]

27. Roa, C.; Hamilton, R.S.; Wenzl, P.; Powel, W. Plant genetic resources: Needs, rights, and opportunities. Trends Plant Sci. 2016, 21, 633-636. [CrossRef]

28. Secretariat of the Convention on Biological Diversity. Bonn Guidelines on Access to Genetic Resources and Fair and Equitable Sharing of the Benefits Arising out of their Utilization; Secretariat of the Convention on Biological Diversity, United Nations Environment Programme: Montreal, QC, Canada, 2002.

29. Secretariat of the Convention on Biological Diversity. Convention on Biological Diversity: Traditional Knowledge, Innovations and Practices; Secretariat of the Convention on Biological Diversity, United Nations Environment Programme: Montreal, QC, Canada, 2010.

30. Schroeder, D.; Pogge, T. Justice and the Convention on Biological Diversity. Ethics Int. Aff. 2009, 23, 267-280. [CrossRef]

31. Brink, M. Implementation of Access and Benefit Sharing Policies in Sub-Sahara Africa: Inventory, Analysis and Proposals. Ministerie van EL\&I. 2013. Available online: http:/ /library.wur.nl/WebQuery/wurpubs/ fulltext/280508 (accessed on 2 June 2017).

32. Geneviève, B.; Catherine, A.; Valérie, J.; Eric, D. Quassia "biopiracy" case and the Nagoya Protocol: A researcher's perspective. J. Ethnopharmacol. 2017, 206, 290-297.

33. Munyi, P.; Mahop, M.T.; Du Plessis, P.; Ekpere, J.; Bavikatte, K. A Gap Analysis Report on the African Model Law on the Protection of the Rights of Local Communities, Farmers and Breeders, and for the Regulation of Access to Biological Resources; Department of Human Resources, African Union: Addis Ababa, Ethiopia, 2012.

34. Zerbe, N. Biodiversity, ownership, and indigenous knowledge: Exploring legal frameworks for community, farmers, and intellectual property rights in Africa. Ecol. Econ. 2005, 53, 493-506. [CrossRef]

35. Wynberg, R. Rhetoric, realism and benefit-sharing. J. World Intell. Prop. 2004, 7, 851-876. [CrossRef]

36. Food and Agriculture Organization (FAO). The International Treaty on Plant Genetic Resources for Food and Agriculture; FAO: Rome, Italy, 2002; 45p.

37. Secretariat of the Convention on Biological Diversity. Nagoya Protocol on Access to Genetic Resources and the Fair and Equitable Sharing of Benefits Arising from their Utilization to the Convention of Biological Diversity: Text and Annex; Secretariat of the Convention on Biological Diversity, United Nations Environment Programme: Montreal, QC, Canada, 2011.

38. Varma, R.V. Access and benefit sharing in India: Challenges ahead. In Biodiversity for Sustainable Development; Springer International Publishing: Berlin, Germany, 2017; pp. 87-96. 
39. Shikongo, S.T. The issue of bio-trade and bio-prospecting in Namibia: An analytical Overview. In Proceedings of the Marrakech ABS Workshop, Marrakech, Morocco, 31 January-4 February 2011; Available online: http:/ / www.abs-initiative.info/uploads/media/Marrakech_01-2011_Shikongo2.pdf (accessed on 6 November 2017).

40. African Regional Intellectual Property Organization (ARIPO). Swakopmund Protocol on the Protection of Traditional Knowledge and Expressions of Folklore; Diplomatic Conference of ARIPO: Swakopmund, Namibia, 9 August 2010.

41. Government of the Republic of Namibia. The Constitution of the Republic of Namibia. 2010. Available online: http: / / www.gov.na/documents /10181/14134/Namibia_Constitution.pdf/37b70b76-c15c-45d49095-b25d8b8aa0fb (accessed on 23 October 2017).

42. Maggs, G.L.; Strohbach, B. Country report on the state of plant genetic resources for food and agriculture. In Proceedings of the First National Workshop on Plant Genetic Resources, Rössing Country Club, Swakopmund, Namibia, 19-21 November 1991; Volume 23.

43. Shikongo, S.T. The issues around the negotiation of the international regime on access and benefit-sharing and the effective participation of local and indigenous communities in this negotiation process: An African perspective. In Proceedings of the International Expert Group Meeting on the Convention on Biological Diversity's International Regime on Access and Benefit-Sharing and Indigenous Peoples' Human Rights, New York, NY, USA, 17-19 January 2007.

44. Tarr, P.; Figueira, M. Namibia's Environmental Assessment Framework: The Evolution of Policy and Practice; Ministry of Environment and Tourism: Windhoek, Namibia, 1999.

45. National Forestry Programme Facility in Namibia. Indigenous Natural Products of Namibia Marketing Information; Namibia Nature Foundation: Windhoek, Namibia, 2009; Available online: www.nnf.org.na/ publications / download/marketing-pamphlet/1.html (accessed on 1 October 2017).

46. United Nations Environment Programme (UNEP). Green Economy Sectoral Study: Biotrade-A Catalyst for Transitioning to a Green Economy in Namibia; United Nations Environment Programme: Geneva, Switzerland, 2012.

47. National Botanical Research Institute. Indigenous Plant Task Team (IPTT): Promoting the Sustainable Utilization of Namibia's Indigenous Plant Resources. 2013. Available online: http:/ /www.nbri.org.na/ sections / economic-botany/INP/IPTT (accessed on 12 November 2017).

48. Krugmann, H.; Katjirua, J. Access to Biological Resources and the Sharing of Benefits from Their Use; Namibia Country Case Study; United Nations Development Programme: Windhoek, Namibia, 2007.

49. Chinsembu, K.C.; Hedimbi, M.; Mukaru, W.C. Putative medicinal properties of plants from the Kavango Region, Namibia. J. Med. Plants Res. 2011, 5, 6787-6797.

50. Chinsembu, K.C. Bioprospecting for 'green diamonds': Medicinal plants used in the management of HIV / AIDS-related conditions. In Indigenous Knowledge of Namibia; Chinsembu, K.C., Cheikhyoussef, A., Eds.; University of Namibia Press: Windhoek, Namibia, 2015; pp. 9-40.

51. Government of the Republic of Namibia (Ministry of Environment and Tourism); National Biodiversity Task Force; Global Environment Facility (GEF); United Nations Environment Programme (UNEP); Germany, Deutsche Gesellschaft für Technische Zusammenarbeit (GTZ). Strategic Plan of Action for Sustainable Development through Biodiversity Conservation 2001-2010; National Biodiversity Task Force: Windhoek, Namibia, 2001.

52. Jauhiainen, J.S.; Hooli, L. Indigenous knowledge and developing countries' innovation systems: The Case of Namibia. Int. J. Innov. Stud. 2017, 1, 89-106.

53. Wynberg, R.; Chennells, R. Green diamonds of the South: An overview of the San-Hoodia case. In Indigenous Peoples, Consent and Benefit Sharing; Springer: Amsterdam, The Netherlands, 2009; pp. 89-124.

54. Vermeylen, S. From life force to slimming aid: Exploring views on the commodification of traditional medicinal knowledge. Appl. Geogr. 2008, 28, 224-235. [CrossRef]

55. Kamau, E.C. Common pools of traditional knowledge and related genetic resources: A case study of San-Hoodia. In Common Pools of Genetic Resources: Equity and Innovation in International Biodiversity Law; Earthscan-Routledge: London, UK, 2013; Volume 40.

56. Lee, R.A.; Balick, M.J. Indigenous use of Hoodia gordonii and appetite suppression. Explor. J. Sci. Heal. 2007, 3, 404-406. [CrossRef] 
57. Saltmarsh, A.C. Francis Masson: Collecting plants for king and country. Curtis's Bot. Mag. 2003, 20, $225-244$. [CrossRef]

58. Chennells, R. San Hoodia Case; A Report for GenBenefit; University of Central Lancashire: Preston, UK, 2007; Available online: www.uclan.ac.uk/genbenefit (accessed on 23 July 2017).

59. Van Heerden, F.R. Hoodia gordonii: A natural appetite suppressant. J. Ethnopharmacol. 2008, 119, $434-437$. [CrossRef]

60. Amusan, L. Politics of biopiracy: An adventure into Hoodia/Xhoba patenting in southern Africa. Afr. J. Tradit. Complement. Altern. Med. 2017, 14, 103-109. [CrossRef] [PubMed]

61. Vermaak, I.; Hamman, J.H.; Viljoen, A.M. Hoodia gordonii: An up-to-date review of a commercially important anti-obesity plant. Planta Med. 2011, 77, 1149-1160. [CrossRef] [PubMed]

62. Drewes, S.E. Natural products research in South Africa: 1890-2010. S. Afr. J. Sci. 2012, 108, 17-24. [CrossRef]

63. Wylie, D. Take Kalahari Hoodia for hunger. In Bitter Roots: The Search for Healing Plants in Africa; University of Chicago Press: Chicago, IL, USA, 2014; p. 165.

64. Makoni, M. San People's Cactus Drug Dropped by Phytopharm; SciDevNet: London UK, 2010; Available online: http:/ / www.scidev.net/global/indigenous/news/san-people-s-cactus-drug-droppedby-phytopharm-1.html (accessed on 20 June 2017).

65. Alikhan, S.; Mashelkar, R.A. Intellectual Property and Competitive Strategies in the 21st Century; Kluwer Law International: Alphen aan den Rijn, The Netherlands, 2004.

66. Schüklenk, U.; Kleinsmidt, A. North-south benefit sharing arrangements in bioprospecting and genetic research: A critical ethical and legal analysis. Dev. World Bioethics 2006, 6, 122-134. [CrossRef] [PubMed]

67. Willcox, M.; Diallo, D.; Sanogo, R.; Giani, S.; Graz, B.; Falquet, J.; Bodeker, G. Intellectual property rights, benefit-sharing and development of "improved traditional medicines": A new approach. J. Ethnopharmacol. 2015, 176, 281-285. [CrossRef] [PubMed]

68. Nijar, G.S. Incorporating traditional knowledge in an international regime on access to genetic resources and benefit sharing: Problems and prospects. Eur. J. Int. Law 2010, 21, 457-475. [CrossRef]

69. Vermeylen, S. Contextualizing 'fair' and 'equitable': The San's reflections on the Hoodia benefit-sharing agreement. Local Environ. 2007, 12, 423-436. [CrossRef]

70. Arewa, O. Piracy, Biopiracy and Borrowing: Culture, Cultural Heritage and the Globalization of Intellectual Property. 2006. Available online: https:/ / papers.ssrn.com/sol3/papers.cfm?abstract_id=596921 (accessed on 10 November 2017).

71. Cole, D.; du Plessis, P. Namibian Devil's claw. In A Case Study on Benefit-Sharing Arrangements; Ministry of Environment and Tourism: Windhoek, Namibia, 2001.

72. National Botanical Research Institute (NBRI). Indigenous natural Products: Devil's Claw. 2017. Available online: http:/ / www.nbri.org.na/sections/economic-botany/INP/sectors/Devils-claw (accessed on 21 October 2017).

73. Cole, D. The Impact of Certification on the Sustainable Use of Devil's Claw (Harpagophytum procumbens) in Namibia; Final Draft Report Prepared for the Food and Agriculture Organization of the United Nations, Non-Wood Forest Products Program; FAO: Rome, Italy, 2003.

74. Stewart, K.M.; Cole, D. The commercial harvest of Devil's claw (Harpagophytum spp.) in Southern Africa: The devil's in the details. J. Ethnopharmacol. 2005, 100, 225-236. [CrossRef]

75. Kim, T.K.; Park, K.S. Inhibitory effects of harpagoside on TNF- $\alpha$-induced pro-inflammatory adipokine expression through PPAR- $\gamma$ activation in 3T3-L1 adipocytes. Cytokine 2015, 76, 368-374. [CrossRef]

76. Torres-Fuentes, C.; Theeuwes, W.F.; McMullen, M.K.; McMullen, A.K.; Dinan, T.G.; Cryan, J.F.; Schellekens, H. Devil's claw to suppress appetite-Ghrelin receptor modulation potential of a Harpagophytum procumbens root extract. PLoS ONE 2014, 9, e103118. [CrossRef]

77. Indigenous Natural Products (INP) Bulletin. Indigenous Natural Products in Namibia; INP Market Bulletin Issue Number 2, May 2011; Millennium Challenge Account Namibia/NBRI: Windhoek, Namibia, 2011.

78. Grote, K. The Increased Harvest and Trade of Devil's Claw (Harpagophytum procumbens) and Its Impacts on the Peoples and Environment of Namibia, Botswana and South Africa; Global Facilitation Unit for Underutilized Species: Rome, Italy, 2003.

79. Mwandemele, O.D.; Mshigeni, K.; Kosina, P.; Kamburona, C. Challenges of domesticating wild plants: The case of the Devil's claw (Harpagophytum spp.) in the Kalahari Desert ecosystem. Discov. Innov. 2006, 18, 175-181. [CrossRef] 
80. Wegener, T. Devil's claw: From African traditional remedy to modern analgesic and anti-inflammatory. HerbalGram 2000, 50, 47-54.

81. Millennium Challenge Account (MCA) Namibia. Indigenous Plant Products in Namibia: The Commercialisation of Indigenous Natural Plant Products in Namibia; Millennium Challenge Corporation, Millennium Challenge Account Namibia, Venture Publications: Windhoek, Namibia, 2014.

82. Nott, K. Survey of Commiphora wildii and other Commiphora species in conservancies in Kunene, Namibia. 2007. Available online: http:/ / www.irdnc.org.na/when-a-tradition-protects-a-culture.html (accessed on 8 November 2017).

83. Sheehama, J.T. Chemical Characterisation of the Volatile Constituents of Essential Oil from Commiphora Wildii (Omumbiri) Resin. Master's Dissertation, University of Namibia, Windhoek, Namibia, 2017.

84. Thomas, B. Sustainable harvesting and trading of mopane worms (Imbrasia belina) in Northern Namibia: An experience from Uukwaluudhi area. Int. J. Environ. Stud. 2013, 70, 494-502. [CrossRef]

85. Maggs, G.L.; Craven, P.; Kolberg, H.H. Plant species richness, endemism, and genetic resources in Namibia. Biodivers. Conserv. 1998, 7, 435-446. [CrossRef]

86. Byers, B.A. Environmental Threats and Opportunities in Namibia: A Comprehensive Assessment; Research Discussion Paper 21; Directorate of Environmental Affairs, Ministry of Environment and Tourism: Windhoek, Namibia, 1997.

87. Government of the Republic of Namibia. A Review of Poverty and Inequality in Namibia; National Planning Commission: Windhoek, Namibia, 2008.

88. Posel, S. UN Biotrade Turning Africa into Financial Resource for Global Governance. 2012. Available online: http:/ / www.activistpost.com/2012/06/un-biotrade-turning-africa-into.html (accessed on 22 August 2017).

89. International Institute for Environment and Development. Encouraging Collaboration: Drafting a New Law to Stop Biopiracy in Namibia. 2016. Available online: https:/ / www.iied.org/encouraging-collaborationdrafting-new-law-stop-biopiracy-namibia (accessed on 8 November 2017).

90. McGown, J. Out of Africa: Mysteries of Access and Benefit Sharing; Edmonds Institute: Edmonds, WA, USA, 2006.

91. Roberts, J. Western medicine in Africa, part II: Ethiopia, East and Southern Africa to 1900. Hist. Compass 2017, 15, e12393. [CrossRef]

92. Berg, C.; Gensthaler, B. Teufelskralle-Rheumamittel im Kalaharisand; Pharmazeutische Zeitung, GOVI-Verlag: Eschborn Germany, 2001.

93. Ceballos, G.; Ehrlich, P.R.; Dirzo, R. Biological annihilation via the ongoing sixth mass extinction signaled by vertebrate population losses and declines. Proc. Natl. Acad. Sci. USA 2017, 114, E6089-E6096. [CrossRef]

94. Kangombe, F.N.; Moses, M.N.; Kwembeya, E.G. The role of the National Botanic Garden of Namibia in plant species conservation. Int. Sci. Technol. J. Namib. 2016, 8, 31-42.

95. Riehl, B.; Zerriffi, H.; Naidoo, R. Effects of community-based natural resource management on household welfare in Namibia. PLoS ONE 2015, 10, e0125531. [CrossRef]

96. Parviainen, T. Role of Community Forestry in Rural Livelihood and Poverty Alleviation in Ohangwena and Caprivi Regions in Namibia. Doctoral Dissertation, Helsingin Yliopisto Helsingfors Universitet University of Helsinki, Helsinki, Finland, 2012.

97. Galloway, F.B. Impacts of Commercialising Commiphora wildii in Two Conservancies in North Western Namibia. Master's Dissertation, University of Cape Town, Cape Town, South Africa, 2014.

98. Cottier, T.; Panizzon, M. Legal perspectives on traditional knowledge: The case for intellectual property protection. J. Int. Econ. Law 2004, 7, 371-399. [CrossRef]

99. Adger, W.N. Social capital, collective action, and adaptation to climate change. Econ. Geogr. 2003, 79, 387-404. [CrossRef]

100. Nkondo, O.M. The future of indigenous knowledge systems (IKS) in global knowledge innovations. Presented at the IKS Workshop, KwaMaritane Game Lodge, South Africa, 17-19 August 2010.

101. Van Overwalle, G. Protecting and sharing biodiversity and traditional knowledge: Holder and user tools. Ecol. Econ. 2005, 53, 585-607. [CrossRef]

102. Yodmongkon, P.; Chakpitak, N. Applying intellectual capital process model for creating a defensive protection system to local traditional knowledge: The case of Mea-hiya community. Electron. J. Knowl. Manag. 2009, 7, 397-534.

103. Mgbeoji, I. Patents and traditional knowledge of the uses of plants: Is a communal patent regime part of the solution to the scourge of biopiracy? Indiana J. Glob. Legal Stud. 2001, 9, 163-186. 
104. Subbiah, S. Reaping what they sow: The basmati rice controversy and strategies for protecting traditional knowledge. BC Int. Comp. Law Rev. 2004, 27, 529.

105. Irawan, C. Protection of traditional knowledge: A perspective on intellectual property law in Indonesia. J. World Intell. Prop. 2017, 20, 57-67. [CrossRef]

106. Jacobs, C.S. Patents of Traditional Medicine Inventions and Their Relationship with Traditional Knowledge Associated with Genetic Resources in Namibia: Proposals for Legal Reform. Master's Dissertation, University of Cape Town, Cape Town, South Africa, 2017.

107. Kennedy, A.M.; Laczniak, G.R. Indigenous intellectual property rights: Ethical insights for marketers. Australas. Market. J. 2014, 22, 307-313. [CrossRef]

108. Ressel, A. Don't Obsess over Protecting Your Idea; EntrepreneurCorner: Johannesburg, South Africa, 2017; Available online: http:/ / m.fin24.com/fin24/Entrepreneurs/Resources/entrepreneurcorner-dont-obsessover-protecting-your-idea-20170927 (accessed on 2 October 2017).

109. Dhanaraj, N.; Sharma, M. An interface between traditional knowledge and intellectual property rights (IPR): An Indian perspective. In Patent Law and Intellectual Property in the Medical Field; IGI Global: Hershey, PA, USA, 2017; pp. 135-147.

110. Gruber, T. Collective knowledge systems: Where the social web meets the semantic web. Web Semant. Sci. Serv. Agents World Wide Web 2008, 6, 4-13. [CrossRef]

111. Hafstein, V.T. The politics of origins: Collective creation revisited. J. Am. Folk. 2004, 117, 300-315. [CrossRef]

112. Doubleday, N.C. Finding common ground: Natural law and collective wisdom. In Traditional Ecological Knowledge: Concepts and Cases; Center for Traditional Knowledge, Canadian Museum of Nature: Ottawa, ON, Canada, 1993; pp. 41-53.

113. Wenger, E. Communities of practice: Learning as a social system. Syst. Think. 1998, 9, 2-3. [CrossRef]

114. Weiner, M. The Global Migration Crisis: Challenge to States and to Human Rights; HarperCollins Series in Comparative Politics; HarperCollins: New York, NY, USA, 1995; Volume XIV, 253p.

115. Sachs, A.; Peterson, J.A. Eco-Justice: Linking Human Rights and the Environment; Worldwatch Paper 127; Worldwatch Institute: Washington, DC, USA, December 1995; Available online: https:/ /www.popline.org/ node/294344 (accessed on 8 November 2017).

116. Helfer, L.R. Toward a human rights framework for intellectual property. UC Davis Law Rev. 2006, 40, 971.

117. Coombe, R.J. The recognition of indigenous peoples' and community traditional knowledge in international law. St. Thomas Law Rev. 2001, 14, 275.

118. Lewis, M. Access and benefit-sharing in the wake of CBD COP10: The Nagoya Protocol and its potential implications for South Africa. South J. Environ. Law Policy 2010, 17, 69-95.

119. Rimmer, M. Submission to the Department of Trade and Industry, the Republic of South Africa on the Intellectual Property Laws Amendment Bill 2008 and the Protection of Indigenous Knowledge. 2008. Available online: https: / / eprints.qut.edu.au/108989/1/108989.pdf (accessed on 13 September 2017).

120. World Intellectual Property Organization. What Is a Trade Secret? 2017. Available online: http:/ /www.wipo. int/sme/en/ip_business/trade_secrets/trade_secrets.htm (accessed on 5 November 2017).

121. Bertino, E.; Khan, L.R.; Sandhu, R.; Thuraisingham, B. Secure knowledge management: Confidentiality, trust, and privacy. IEEE Trans. Syst. Man Cybern. Part A Syst. Hum. 2006, 36, 429-438. [CrossRef]

122. Government of the Republic of Namibia. University of Namibia Act 18 of 1992. 1992. Available online: https: / / www.scribd.com/document/16634618/University-of-Namibia-Act-18-of-1992 (accessed on 5 December 2017).

123. Government of the Republic of Namibia. Namibia University of Science and Technology Act 7 of 2015; 2015. Available online: http:/ / www.lac.org.na/laws/annoSTAT/Namibia\%20University\%20of\%20Science $\%$ 20and\%20Technology\%20Act\%207\%20of\%202015.pdf (accessed on 5 December 2017).

124. Etzkowitz, H.; Leydesdorff, L. The triple helix-university-industry-government relations: A laboratory for knowledge based economic development. EASST Rev. 1995, 14, 14-19.

125. Chinsembu, K.C. Bioprospecting the Harambee Prosperity Plan: How will Namibia's new access and benefit sharing law impact research in Namibian universities? Int. Sci. Technol. J. Namib. 2017, 9, 1-8.

126. Martinez, S.I.; Biber-Klemm, S. Scientists-Take action for access to biodiversity. Curr. Opin. Environ. Sustain. 2010, 2, 27-33. [CrossRef]

127. Schroeder, D. Informed consent: From medical research to traditional knowledge. In Indigenous Peoples, Consent and Benefit Sharing; Springer: Amsterdam, The Netherlands, 2009; pp. 27-51. 
128. Madhusudan, M.D.; Shanker, K.; Kumar, A.; Mishra, C.; Sinha, A.; Arthur, R.; Datta, A.; Rangarajan, M.; Chellam, R.; Shahabuddin, G.; et al. Science in the wilderness: The predicament of scientific research in India's wildlife reserves. Curr. Sci. 2006, 91, 1015-1019.

129. Kamaljit Bawa, S. Hurdles for conservation science in India. Curr. Sci. 2006, 91, 1005.

130. Pethiyagoda, R.; Gunatilleke, N.; de Silva, M.; Kotagama, S.; Gunatilleke, S.; de Silva, P.; Meegaskumbura, M.; Fernando, P.; Ratnayeke, S.; Jayewardene, J.; et al. Science and biodiversity: The predicament of Sri Lanka. Curr. Sci-Bangalore 2007, 92, 426.

131. Prathapan, K.D.; Dharma Rajan, P.; Narendran, T.C.; Viraktamath, C.A.; Aravind, N.A.; Poorani, J. Death sentence on taxonomy in India. Curr. Sci. 2008, 94, 170-171.

132. Jinnah, S.; Jungcurt, S. Could access requirements stifle your research? Science 2009, 323, 464-465. [CrossRef] [PubMed]

133. Crouch, N.R.; Douwes, E.; Wolfson, M.M.; Smith, G.F.; Edwards, T.J. South Africa's bioprospecting, access and benefit-sharing legislation: Current realities, future complications, and a proposed alternative. S. Afr. J. Sci. 2008, 104, 355-366.

134. Neves, K. Reproducing Empire, Subverting Hegemony? Botanic Gardens in Biodiversity Conservation; EnviroSociety: Santa Cruz, CA, USA, 4 December 2014; Available online: http://www.envirosociety. org/2014/12/reproducing-empire-subverting-hegemony-botanic-gardens-in-biodiversity-conservation/ (accessed on 8 November 2017).

135. Parry, B. The fate of the collections: Social justice and the annexation of plant genetic resources. In People, Plants and Justice: The Politics of Nature Conservation; Zerner, C., Ed.; Columbia University Press: New York, NY, USA, 2000; pp. 374-402.

136. Hulme, P.E. Addressing the threat to biodiversity from botanic gardens. Trends Ecol. Evol. 2011, 26, 168-174. [CrossRef] [PubMed]

137. Ward, C.D.; Parker, C.M.; Shackleton, C.M. The use and appreciation of botanical gardens as urban green spaces in South Africa. Urban For. Urban Green. 2010, 9, 49-55. [CrossRef]

138. Gaio-Oliveira, G.; Delicado, A.; Martins-Loução, M.A. Botanic gardens as communicators of plant diversity and conservation. Bot. Rev. 2017, 83, 208-302. [CrossRef]

139. Da Costa, M.L.M.; Maunder, M.; Pereira, T.S.; Peixoto, A.L. Brazilian botanic gardens: An assessment of conservation capacity. Sibbaldia J. Bot. Gard. Hortic. 2017, 14, 97-117.

140. Oldfield, S.F. Botanic gardens and the conservation of tree species. Trends Plant Sci. 2009, 14, 581-583. [CrossRef]

141. Badley, C.; Hill, D.J.; Wray, N. Inadequate accession data compromises the conservation value of plant collections. Sibbaldia J. Bot. Gard. Hortic. 2017, 2, 5-19.

142. Watanabe, M.E. The Nagoya Protocol: Big steps, new problems. BioScience 2017, 67, 400. [CrossRef]

143. Wynberg, R. Making sense of access and benefit sharing in the rooibos industry: Towards a holistic, just and sustainable framing. S. Afr. J. Bot. 2017, 110, 39-51. [CrossRef]

144. National Commission for Research, Science and Technology (NCRST). The National Programme on Research, Science, Technology and Innovation (NPRSTI) 2014/15 to 2016/17; NCRST: Windhoek, Namibia, 2014.

(C) 2020 by the authors. Licensee MDPI, Basel, Switzerland. This article is an open access article distributed under the terms and conditions of the Creative Commons Attribution (CC BY) license (http://creativecommons.org/licenses/by/4.0/). 